\title{
Underwater video techniques for observing coastal marine biodiversity: A review of sixty years of publications (1952-2012)
}

\author{
Delphine Mallet $^{\mathrm{a}, \mathrm{b}, *}$, Dominique Pelletier ${ }^{\mathrm{a}}$
}

a IFREMER, Unité de Recherche Lagons, Ecosystèmes et Aquaculture Durable en Nouvelle Calédonie (LEADNC), Nouméa, New Caledonia

${ }^{\mathrm{b}}$ EA 4243 LIVE, Université de la Nouvelle-Calédonie, Nouméa, New Caledonia

*: Corresponding author : Delphine Mallet, email addresses : delphine.mallet@yahoo.fr ; Delphine.Mallet@ifremer.fr

\begin{abstract}
:
Underwater video techniques are increasingly used in marine ecology studies. Technological progress regarding video cameras, sensors (such as sounders), battery life and information storage make these techniques now accessible to a majority of users. However, diver-based underwater visual censuses, and catch and effort data, remain the most commonly used for observing coastal biodiversity and species. In this paper, we review the underwater video techniques that have been developed since the 1950 s to investigate and/or monitor coastal biodiversity. Techniques such as remote underwater video, whether baited or not, diver-operated video and towed video are described, along with corresponding applications in the field. We then analyse the complementary of techniques, first from studies comparing video techniques with other observation techniques, whether video-based or not, and second by documenting their respective cost efficiencies. These findings are discussed with respect to current challenges in monitoring and investigating coastal biodiversity. Video should be more often considered and used, either in addition to or as an alternative to diver-based, fishing and acoustic techniques, as it may be particularly suited for monitoring coastal biodiversity in a variety of areas and on larger scales than hitherto and within an ecosystem-based approach to management and conservation.
\end{abstract}

\section{Highlights}

Underwater video is increasingly used in marine ecology. Video is less used than catch and underwater visual census. Video techniques comprise baited, unbaited, towed and diver-operated techniques. Video is a cost-efficient complement or alternative to other observation techniques.

Keywords: Underwater video ; Monitoring ; Coastal biodiversity ; Fish ; Habitat 


\section{Table of contents}

1. Introduction

2. State of the art regarding underwater video techniques

2.1. Remote Underwater Video (RUV)

2.2. Baited Remote Underwater Video (BRUV)

2.3. TOWed Video (TOWV)

2.4. Diver-Operated Video (DOV)

2.5. Stereo-video technique

2.6. Technological progress

3. Underwater video: Where is it used and what is it used for?

4. Complementarity of techniques

4.1. Comparative studies

4.2. Cost-efficiency considerations

\section{Underwater video in the light of current monitoring challenges}

5.1. Is image analysis an issue?

5.2. Observation area and duration

5.3. Non-obtrusive observations of species assemblages?

5.4. Temporal and spatial replication

5.5. Which technique for observing and monitoring coastal biodiversity?

5.6. Future prospects for underwater video monitoring 


\section{Introduction}

The conservation of marine and coastal biodiversity and associated ecosystem services through ecosystem-based management (Christensen et al., 1996) requires appraising a wide array of biodiversity components on large spatial scales. Biodiversity here encompasses mostly fish and macroinvertebrate species, whether or not exploited, and corresponding assemblages and habitats. Biodiversity is rarely observed and assessed on such scales due to observation costs. The main techniques used to study and monitor biodiversity are either extractive (e.g. fishing, dredging), based on acoustics, or based on Underwater Visual Censuses (UVC).

Extractive techniques have been used mostly for fish, macrobenthic organisms and endogenous fauna, primarily for the assessment of fished populations. Fishing-based surveys (see e.g. Petitgas et al., 2009) focus on catchable species, whether or not exploited.

The potential of catch-based surveys for an ecosystem approach to fisheries management has been addressed by Trenkel and Cotter (2009) and Jouffre et al. (2010), among others. Catch-based monitoring provides information about catchable species, but not on other species, nor on habitat. Catchability may vary across species and as a function of weather conditions (Trenkel and Cotter, 2009) and vessels (Pelletier, 1991). Sampling effort by fisheries is considerable, but data interpretation may be tricky due to the uncontrolled sampling design. Scientific catch surveys circumvent this problem, but provide small sample sizes compared to fisheries catch (Trenkel and Cotter, 2009). In addition, extractive techniques have an impact on biodiversity, which may not be desirable in the context of monitoring conservation strategies. Rotenone sampling is similar to fishing, in that it is extractive, focuses on fish species, and selects only part of the fish assemblage (Robertson and Smith-Vaniz, 2008). It is thus used more for inventories and small-scale observations than for monitoring. Underwater acoustics is currently effective for pelagic and semidemersal species, and for zooplankton (Trenkel et al., 2011). However, species present in the acoustic data have to be identified through complementary techniques, and benthic 
species are not well-observed. For instance, Jones et al. (2012) combined acoustics and video to estimate rockfish biomass in untrawlable areas.

In shallow areas, UVC techniques have been used for over sixty years to monitor fish, macrobenthic organisms and habitats (Brock, 1954). They are considered to be reliable and cost effective (Thresher and Gunn, 1986). Advantages and disadvantages of UVC for estimating fish abundance and diversity have been reported and discussed in several papers (Chapman et al., 1974; Sale, 1980; Brock, 1982; Harmelin-Vivien et al., 1985; Watson et al., 1995; Thompson and Mapstone, 1997; Willis, 2001; Kulbicki et al., 2010; Dickens et al., 2011). The main limitation of UVC lies in the need for divers' presence underwater, which influences the observation of vagile macrofauna, restricts the number of observations that can be carried out, and constrains depth observation.

In recent years, underwater video techniques have been increasingly used for observing macrofauna and habitat in marine ecosystems (see e.g. Sarradin et al., 2007 for a review concerning deep ecosystems). Technological progress regarding video cameras, sensors paper did not document the various video techniques and their applications. To our 51 knowledge, there are no published papers describing underwater video techniques and their applications, and discussing their respective relevance for observing shallow water marine biodiversity. Yet many papers have been published using video techniques in this context,

54 and video-based techniques have considerably evolved over time. The present review 55 focuses on the video techniques developed and used for this purpose, from the first 
published papers through to 2012. Section 2 describes the main techniques, along with technological issues. Applications of each technique are summarized in section 3. In section 4, studies comparing video techniques with other observation techniques are listed, and their conclusions are summarized. The last section discusses the potential of video techniques for monitoring and investigating biodiversity issues in coastal environments, in order to provide guidance in choosing among techniques.

62

\section{State of the art regarding underwater video techniques}

Literature searches were conducted using the ISIS Web of Knowledge ${ }^{\mathrm{SM}}$ and Google

Scholar for relevant keywords, including "underwater video", "underwater television", "remote underwater video", "baited video", "BRUV", "towed video", "video transect" and "stereovideo". In addition to database searches, we also hand-checked the reference lists of all studies retrieved to identify all relevant primary research published in peer-reviewed journals, books and proceedings of international conferences. Thus a substantial amount of grey literature was not taken into account in this review.

We restricted the literature search to environments shallower than $100 \mathrm{~m}$. At greater depths, observations are more constrained by technological issues, scuba diving is not routinely feasible, and artificial light is needed. Papers pertaining to freshwater ecosystems were not included in the review either. Studies using photography, photogrammetry, underwater video for evaluating fishing gear catchability or acoustic techniques, and video tracking (Delcourt et al., 2012) fell outside the scope of the paper. The search resulted in a list of 182 peer-reviewed papers, taking into account the majority of peer-reviewed papers within the scope of the present review. As video systems are increasingly used around the world, the number of published studies has greatly increased over the last decade $(67 \%$ of the papers were published from 2002 onwards). Papers were sorted according to four main techniques: remote underwater video, baited remote underwater video, towed video and diver-operated video. Note that the term "remote" is used here to designate a technique which does not require human presence underwater, while the term "autonomous" indicates 

a system that is not linked to a vessel or a platform. Baited Remote Underwater Video will be denoted BRUV following most studies using this technique, while unbaited Remote Underwater Video will be simply termed RUV for the sake of concision. RUV thus includes here all remote video systems that are not baited, whether dropped from the boat or set by divers. Note that trademarks on "BRUVS" and "RUVS" of the Australian Institute of Marine Science were not used as they are too specific and do not encompass all the techniques discussed in this review.

\subsection{Remote Underwater Video (RUV)}

The first published work reporting the use of underwater video systems in the coastal environment dates back to the 1950s. The Scottish Marine Biological Association of Millport developed an underwater video program in 1948, and tested it in the Aquarium of the Zoological Society of London in 1949 (Barnes, 1952, 1953). In 1951, the Royal Navy constructed a system which was successfully used to identify a Royal Navy submarine lost at sea in 1951. It then served for other projects on bottom fauna (Barnes, 1955) as suspended in a mid-water environment (Backus and Barnes, 1957) and for other Navy applications (Barnes, 1963). RUV has used more frequently in marine sciences since the 1960s (Table 1). It provided the first data on fish movement and behaviour in daytime and at night, which had not been previously studied without human disturbance (Barnes, 1952; Kumpf and Lowenstein, 1962; Booda, 1966; LaFond, 1968). RUV systems exhibit different designs and technical features, including additional sensors, and can be distinguished in terms of their autonomy (linked or autonomous).

\section{Linked systems}

The system developed by LaFond et al. (1961) filmed from the surface to the bottom (20 m depth) while moving up and down a vertical-rail track placed under a platform (Table 1). It was used to study diurnal and nocturnal fish movements along with plankton dispersion (see section 3). Over the same period of time, an experimental RUV equipped with hydrophones 
112 and lights for night vision (AC-RUV, "AC" for acoustic) was developed by Kumpf and

113 Lowenstein (1962) and Kronengold et al. (1964). The system was permanently set on sea

114 bottom in the Bahamas (Steinberg and Koczy, 1964), in order to (i) identify the sounds

115 present in a supposedly silent environment; (ii) learn about wildlife behavioural response to

116 sound disturbance; (iii) describe the temporal patterns of sounds, and (iv) evaluate the

117 advantages and limitations of systems coupling video and acoustics. Initial problems

118 resulting from a large system size and from fouling on the camera housing led to an

119 improved smaller AC-RUV system (Holt, 1967; Stevenson, 1967; Table 1).

120 More recently, Stokesbury et al. (2004) developed a vertical RUV system (Table 1) to

121 study scallop distribution off the northeastern coast of the United States. Tyne et al. (2010)

122 used the same system to record benthic habitats in Western Australia. The camera filmed a

$1231 \mathrm{~m}^{2}$ bottom quadrat area at depths ranging between 2 and $16 \mathrm{~m}$. Recorded images were

124 automatically analysed by a computer, providing estimates of the percent seagrass cover,

125 and the type and abundance of sponges within the quadrat.

126 The latest linked systems are permanent observatories using cables for energy supply,

127 data transfer and instrument control (Aguzzi et al., 2012). In an area south of Taiwan, Jan et

128 al. (2007) placed a system linked to an internet video server, making the videos viewable in

129 real time on the World Wide Web. In the western Mediterranean, Aguzzi et al. (2011) set the

130 OBSEA system at $20 \mathrm{~m}$ depth to monitor fish assemblages (Table 1).

Autonomous systems

133 Fedra and Machan (1979) used the first autonomous RUV in the North Adriatic Sea

134 (Mediterranean) (Table 1). The system was set on the seabed by a diver and then left for a

135 week, in order to study the behaviour and distribution of benthic and demersal species, their

136 feeding activities and movement patterns, along with species interactions and the influence

137 of environmental conditions (see section 3). Chabanet et al. (2012) recently introduced a

138 similar system to investigate the temporal variability of undisturbed fish populations over a

139 twenty day time period. Dunbrack and Zielinski (2003) devised a system with a camera 
140 mounted on a tripod. It was placed at the edge of the reef slope to film down the reef and

141 study the ecology, behaviour and population status of the bluntnose sixgill shark (Hexanchus 142 griseus) in the Georgia Strait, British Columbia (see also Dunbrack, 2006, 2008).

143 The rotating RUV system (ROT-RUV: "ROT" for rotation, termed "STAVIRO" by the 144 authors) of Pelletier et al. (2012) (Table 1) is fixed on a tripod, dropped from the boat onto 145 the seabed, and retrieved using buoys and rigging. It has been used in the New Caledonian 146 lagoon (South Pacific) since 2007 and in the Western Mediterranean since 2010 to study and 147 monitor the spatio-temporal distribution of marine macrofauna and habitat (Pelletier et al., 148 2012; D. Mallet, M. Bouchoucha, D. Pelletier, unpublished data). Unlike other RUV systems, 149 the $360^{\circ}$ view afforded by rotation provides panoramic images and a much larger surveyed 150 area than fixed systems, while avoiding the image distortion characteristic of fisheye lenses.

151 Potential double counting is minimized by paying particular attention to the direction of fish

152 movement with respect to rotation, and by calculating the mean abundance over rotations, to 153 average out the variability between rotations (Pelletier et al., 2012).

154 Most of the above techniques were implemented with the help of divers, except for 155 Stokesbury et al. (2004), Tyne et al. (2010) and Pelletier et al. (2012). Only four RUV 156 techniques identified in this review did not use artificial light (Stevenson, 1967; Petrell et al., 157 1997; Dunbrack and Zielinski, 2003; Pelletier et al., 2012).

158 Video systems remaining underwater for several days inevitably face the problem of 159 fouling, i.e. the accumulation of organisms, impairing the quality of images. Yet in the 160 literature examined, this problem was raised and addressed only by Stevenson (1967) and 161 Chabanet et al. (2012), who used automatic windshield wipers to clean the lens surface 162 regularly.

\subsection{Baited Remote Underwater Video (BRUV)}

A BRUV system uses either a single camera or two cameras (see subsection 2.5)

166 filming the area surrounding a bait used to attract fish. The bait bag is placed close to the 167 camera, at a distance ranging between $0.5 \mathrm{~m}$ and $1.5 \mathrm{~m}$ (Ellis and DeMartini, 1995; Willis 
168 and Babcock, 2000; Heagney et al., 2007). The species attracted and the bait range of action

169 depend on the bait used (Harvey et al., 2007; Stobart et al., 2007; Wraith, 2007). Pilchards

170 (Sardinops sp.) are currently used in most studies (McLean et al., 2010, 2011; Watson et al., 171 2010; Bassett and Montgomery, 2011; Göetze et al., 2011; Harvey et al., 2012a; Langlois et 172 al., 2012a, 2012b). BRUV systems are directly deployed from the boat (Watson et al., 2005,

173 Cappo et al., 2007a, Bassett and Montgomery, 2011). Willis and Babcock (2000) and

174 Watson et al. (2005) showed that a soak time of 25 to 40 minutes underwater was required

175 to obtain representative observations for the majority of fish species, but they recommended

176 a duration of 50 to 60 minutes for observing most target fish species in the census. The main

177 differences among BRUV systems concern the orientation of the system in relation to the sea

178 bottom (horizontal or vertical, Table 2), which result in distinct observed abundances and

179 species compositions (Langlois et al., 2006; Wraith, 2007). BRUV has also been used with

180 infrared light to study nocturnal fish; for example Bassett and Montgomery (2011) studied the

181 olfactory capabilities of nocturnal fish species and their influence on response to bait using

182 this system.

183

184

185

186

187

\section{Horizontally oriented BRUV}

Horizontal BRUV (H-BRUV) (Ellis and DeMartini, 1995) provides a wide viewing angle for observing the area surrounding the bait. An array of species can be observed, in particular those not approaching the bait bag because of fish behaviour or competition for the bait (Cappo et al., 2004; Harvey et al., 2007). H-BRUV systems have been mainly used to study spatio-temporal variations in reef fish assemblages, the influence of depth and location upon fish and species distribution, and the effect of MPAs on biodiversity (Cappo et al., 2007b and section 3). H-BRUVs are generally set on the seafloor, though Heagney et al. (2007) used mid-water BRUV to study pelagic fish.

\section{Vertically oriented BRUV}


Vertical BRUV (V-BRUV) has been used for studying the size and abundance of 196 carnivorous fish (Babcock et al., 1999; Willis and Babcock, 2000) and the effect of protection 197 by MPAs (Willis et al., 2000, 2003; Denny and Babcock, 2004; Denny et al., 2004; Willis and 198 Millar, 2005). The restricted field of vision due to the camera pointing downwards ensures a constant field of view and a constant focal length, particularly where water clarity or 200 topography varies between observations (T. Willis, personal communication). Langlois et al. 201 (2006) suggested that some species would rarely approach the system when the camera 202 was positioned above the bait. Other authors suggested that recent V-BRUV does not affect 203 blue cod and various other species (T. Willis, personal communication). Lightweight stands 204 have been shown to provide precise relative density estimates of carnivorous fishes (Willis et 205 al., 2000).

\subsection{TOWed Video (TOWV)}

Machan and Fedra (1975) introduced the first TOWed Video technique (TOWV) in 209 shallow waters. The system was towed by a vessel at low speed $\left(0.1\right.$ to $\left.1 \mathrm{~m} \mathrm{~s}^{-1}\right)$. TOWV films 210 along a transect of predefined size and trajectory (30 m to $20 \mathrm{~km})$. The various systems 211 developed (Table 3) were linked to the vessel by a coaxial cable and a rope. The main 212 difference among them lies in the position at which the system operates in the water column, 213 i.e. seabed or mid-water.

\section{Seabed TOWV}

216 In the coastal domain, the first TOWV systems were towed on the seabed using a sledge 217 (seabed-TOWV, Table 3). These were used in the Mediterranean Sea (Machan and Fedra, 218 1975), in South-West England (Holme and Barrett, 1977) and in Alaska (Spencer et al., 219 2005, and Rooper and Zimmermann, 2007). The video camera is slightly angled downwards 220 on the sledge, which carries additional equipment (Table 3). Seabed-TOWVs have been 221 used to study sea floor and epifaunal species (mostly crustaceans and flat fish) (see section 
222 3). It should be noted that in shallow waters such as lagoon areas, vagile species were found

223 to be sensitive to the boat noise (D. Pelletier and G. Hervé, unpublished data).

Mid-water-TOWV

Mid-water-TOWV systems are more recent than seabed-TOWVs in shallow waters (Norris et al., 1997). These systems are towed at a constant elevation in the water column, 228 thus providing a wider view of the seafloor compared to seabed-TOWVs. The system of Riegl et al. (2001) is set on each side of the boat with vertical tubes that can be lowered or raised between 0.5 and $3.5 \mathrm{~m}$ below the sea surface, so as to adjust to varying depth (Table 3). Most mid-water-TOWVs are equipped with a depth sounder (Hayashizaki and Ogawa, 2006; see also Schaner et al., 2009, for a freshwater application). They have mostly been used to characterize, quantify and assess changes in benthic flora (seagrass, macro-algae 234 and coral) and fauna.

\subsection{Diver-Operated Video (DOV)}

The diver-operated video technique (DOV) consists of a diver holding a video system and filming a defined area. Similarly to UVC, the observation area may vary in size (transects from 2 to $500 \mathrm{~m}$, Table 4) and shape (along a predefined line, inside a quadrat, or rotating

240 around a fixed point). The diver is sometimes towed (Carleton and Done, 1995; Vogt et al., 241 1997; Kenyon et al., 2006), recalling the "Manta tow" technique, where a towed snorkeler 242 implements a transect (Fernandes, 1990). Towed DOV has been used to record benthic 243 habitat along long transects (up to $500 \mathrm{~m}$ long).

244 The DOV technique (Alevizon and Brooks, 1975) involves a diver filming vertically along 245 a transect line. DOV is generally conducted at a constant swimming speed over the entire 246 transect $\left(0.1\right.$ to $3 \mathrm{~m} \mathrm{~s}^{-1}$, Table 4). Elevation above the seafloor ranges from 0.15 to $0.5 \mathrm{~m}$ 247 (parameter documented in 16 papers out of 22). But in some cases, transects are conducted 248 at a larger elevation ( 1 to $3 \mathrm{~m}$ ) to ensure a wider viewing angle (Table 4). A reference bar 249 attached to the camera housing is sometimes used to control the camera elevation (Leonard 
and Clark, 1993; Vogt et al., 1997; Rogers and Miller, 2001; Lam et al., 2006; Cruz et al., $2512008)$.

252 Pelletier et al. (2011) presented the browsing video transect technique, where the diver 253 browses inside the strip transect area, at varying elevation, speed and angle, and zooming 254 when needed. This technique mimics the behaviour of UVC divers in strip transects. These 255 authors demonstrated that more individuals and species were recorded from browsing 256 transects than from straight ones conducted at a constant elevation. and records images, mimicking the UVC stationary point count technique (Bohnsack and Bannerot, 1986). DOV was also used to study fish behaviour by Krohn and Boisclair (1994) (energy expenditure of swimming fish) and Hall and Hanlon (2002) (observation of particular 261 individuals for up to $1.5 \mathrm{~h}$ ).

\subsection{Stereo-video technique}

The stereo-video technique is not additional to those described above, but it involves a particular recording that produces a 3-dimensional (3D) image. It was developed by Harvey and Shortis (1995) to improve fish size estimation by divers. The technique simultaneously uses two cameras to record the same scene. Left and right images are synchronized on the computer based on a light-emitting diode (LED) placed at $2.5 \mathrm{~m}$ from the cameras and seen on both images. Images are then cross-checked from ad hoc software to obtain a 3D image allowing individual size measurement. A 1.4 m distance between the two cameras was found

271 to provide a trade-off between the precision afforded by a greater distance and diver's ability 272 to manoeuvre the system (Harvey and Shortis, 1995). This system recorded and measured 273 individuals in a distance range of 2 to $10 \mathrm{~m}$, depending on underwater visibility. Length 274 measurements were found to be more accurate and repeatable when the orientation of the 275 subjects to the stereo-cameras was less than $50^{\circ}$ (Harvey and Shortis, 1995, 1998). Stereo276 video has been shown to provide more accurate estimates of both fish length and distance 277 than visual estimation by divers (Harvey et al., 2001a, 2001b, 2002a, 2004) or single video 
278 (Harvey et al., 2002b). As such, it also helps distinguishing individuals (Harvey et al., 2003, 279 2007).

280 The stereo system has been adapted to all underwater video techniques (RUV and 281 BRUV, TOWV, and DOV), but it has been mostly implemented on H-BRUV systems (Watson 282 et al., 2007, 2009; Chatfield.et al., 2010; McLean et al., 2010, 2011; Göetze et al., 2011; Birt 283 et al., 2012; Dorman et al., 2012; Fitzpatrick et al., 2012; Harvey et al., 2012a, 2012b, 2012c; 284 Langlois et al., 2012a, 2012b). Several comparisons of underwater observation techniques 285 used stereo-video (Watson et al., 2005, 2010; Langlois et al., 2010). Shortis et al. (2009) 286 provide a detailed review of the status of underwater stereo-video measurement and marine 287 and ecology applications. With the same objective of measuring fish, Heppell et al. (2012) 288 used two lasers fixed on each side of a single camera, rather than stereo-video.

\subsection{Technological progress}

The first video systems used (Barnes, 1952, 1953, 1955; Backus and Barnes, 1957, Myrberg et al., 1969, 1973) suffered from (i) difficulties in setting and retrieving systems; (ii) malfunctioning of electronically driven systems; and (iii) the limitations of video sensors which severely impaired image quality.

Various systems have been developed and used over time (Figure 1). The emergence 296 and evolution of such systems was primarily driven by technological progress, enabling 297 considerable improvements in performance, while making these tools more robust, smaller 298 and cheaper. The digital revolution led to increased sensor resolution, with a dramatically 299 improved image quality, in particular with the advent of High Definition (HD). Regarding energy supply, batteries have become smaller and more powerful. Data storage devices now make it possible to record and archive more images, since camera internal memory or

302 Secure Digital (SD) cards can now store up to 120 Gigabytes (GB), while the capacity of 303 standard external hard drives is 1 or 2 Terabyte (TB). The increasing volume of observation 304 files is therefore matched by a corresponding increase in information storage capacities. 


\section{Underwater video: Where is it used and what is it used for?}

Video systems are increasingly used around the world, particularly over the last decade

308 (Figure 1). Nevertheless, there are not many teams using these techniques. Numerous studies have been published in Australia (63 papers from 1995 to 2012), the USA (24 papers from 1957 to 2012) and New Zealand (24 papers from 1995 to 2011), and in comparison,

311 relatively few papers from other countries (Figure 2 and Supplementary Material A). The first

312 publications on RUV systems originated in Europe (United Kingdom in 1952) and North

313 America (USA in 1957), and then extended to all continents (Oceania in 1995, Asia in 1997

314 and Africa in 2008). Twenty papers were published from the Bahamas AC-RUV between

3151962 and 1973. BRUV has mainly been used in Australia since 2003 (32 of the 52 BRUV-

316 based papers), and in New Zealand since 1999 (11 papers). In Australia only H-BRUV has

317 been used, whereas in New Zealand V-BRUV has mostly been used (9 of the 11 BRUV-

318 based papers). Studies involving TOWV and DOV are both more widespread and less

319 numerous, with respectively 23 and 28 papers published since 1975 . Note that the grey

320 literature and studies outside the scope of this review (deep environment and freshwater)

321 contain a large amount of work which has not been cited here (including some of the authors'

322 work).

323 The techniques described in the previous section have been used for a variety of 324 purposes in the context of coastal biodiversity. Applications were classified according to five 325 main subjects (Table 5) to provide an overview. Studies of animal behaviour and activity are 326 a major field of application (52 references published between 1952 and 2012). Six papers 327 used video to investigate the effect of human-induced disturbances upon species behaviour. 328 Forty-eight papers investigate spatial and temporal patterns of fish abundance, size and of 329 fish assemblage composition, in particular to appraise the effects of habitat, anthropogenic 330 pressures and MPAs. Thirty-two references dealt with habitat mapping and benthic cover 331 monitoring, but benthos monitoring at species level was addressed by only four references.

332 Not surprisingly, video techniques have been specialized, depending on these areas of 333 application. RUV has been preferably used for behaviour-related studies (45 references), 
334 and only recently become of interest for assessing species response to environmental 335 conditions and habitat through spatially-replicated designs (8 references from 2008). In 336 contrast, BRUV has been extensively used for this latter purpose (25 references), with an 337 emphasis on size estimation through stereo-video, whereas it has been hardly used for 338 behavioural studies. TOWV has been almost exclusively used for habitat mapping and 339 monitoring purposes (15 references); studies mostly focused on benthic macrofauna (e.g. 340 coral cover and scallops) and macroflora (e.g. sea grass and algae), though some examined 341 demersal fish species. DOV has also been used for assessing fish abundance and 342 assemblages (13 references), habitat mapping and monitoring (15 references), and 343 investigating fish behaviour (2 references). It is important to note that each technique was 344 tested in both temperate and tropical ecosystems. It should also be underlined that Table 5 345 provides an average picture over the review period. Technological progress entails new 346 observation capacities, and therefore new fields of investigation, such as exemplified by 347 recent applications of RUV to fish and habitat monitoring. In addition to these applications, 348 the great potential of video for addressing specific biodiversity-related topics was also 349 illustrated by unusual applications, e.g. seals in underwater caves (Dendrinos et al., 2007).

350 Lastly, attention was paid to the kind of information collected by each technique. Fish 351 species are most often identified at the lowest possible taxonomic level, notwithstanding a 352 small fraction of individuals, in general small species, identified only at higher levels such as 353 genus or family (see e.g. Pelletier et al., 2011). This must be taken into account when 354 calculating metrics based on species counts. In some instances, metrics may only be 355 calculated at genus or family level. In general, epifauna and epiflora are identified according 356 to broad categories, e.g. sponges (Tyne et al., 2010), macroalgae (Bucas et al., 2007), 357 tunicates and ophiuroids (Carbines and Cole, 2009). Benthos and habitat are generally 358 characterized through percent covers of the sea bottom. In all cases, the species that can be 359 observed in a reliable way must be carefully listed. Cryptic species are poorly observed and 360 the limitations of visual counts due to underwater visibility are also valid for video techniques. 361 Small species may be more difficult to identify from video images than from visual counts, 
whereas diver-avoiding species are more likely observed from diver-free video systems

363 (Mallet et al., 2014).

364 A large number of metrics can then be obtained from all the techniques (Table 6).

365 Species are counted over the observation duration to provide presence/absence, 366 occurrences and species richness. In the case of vagile species, abundance is estimated 367 over the whole video sequence or part of it for RUV, DOV and TOWV. In contrast, for BRUV 368 the metric used is the time of first appearance per species (Wraith, 2007), and most often 369 MaxN, the maximum abundance per species seen over the observation period (Ellis and 370 DeMartini, 1995). MaxN is a conservative estimate of abundance (Willis et al., 2000). 371 Bacheler et al. (2013) proposed using the mean number of fish observed in a series of 372 snapshots over a viewing interval (MeanCount). Schobernd et al. (2013) compared MaxN 373 and MeanCount from simulations, laboratory experiment and modelling. They found that 374 MeanCount was generally linearly related to true abundance with a variability similar to 375 MaxN. Fixed species and habitat are quantified either through abundance or percent cover. 376 Estimating the size of individuals is generally done using stereo-video. Counts may also be 377 assigned to size classes to avoid the issue of size estimation. Lastly, depending on the way 378 cameras are set, video may allow other metrics to be considered, such as the number of 379 bites from herbivores, the occurrence of activities, or parameters describing habitat (Table 6).

\section{4. Complementarity of techniques}

\section{4.1. Comparative studies}

383 From our literature search, we identified forty-two papers comparing two or more 384 observation techniques (Table 7). More than 65\% (28 out of 42) of papers compared UVC 385 with a video technique: RUV (5 papers), TOWV (3), DOV (8), BRUV (9), and stereo-RUV (5). 386 As video is perceived as a relatively new observation technique, it was often compared to 387 UVC, which is commonly used for observing fish communities and habitats in shallow areas. 388 Other comparisons involved two or more video techniques for (i) testing the effect of using 389 two cameras compared to a mono-camera (stereo-RUV versus RUV); (ii) testing the effect of 
baiting (BRUV versus RUV); and (iii) evaluating their respective relevance for studying reef

391 fish assemblages (BRUV versus TOWV, stereo-RUV versus stereo-DOV, stereo-BRUV and 392 stereo-DOV). Finally, several papers compared underwater video with, on the one hand, 393 experimental fishing (two papers dealing with RUV, five with BRUV, two with stereo-BRUV 394 and one with TOWV) and, on the other, acoustic techniques (one paper about BRUV).

395 Comparisons always used metrics based on species counts (species richness, 396 taxonomic diversity, and frequency of occurrence), and on abundance estimates (Table 8). 397 Note that each study presented a number of distinct results, which may vary across taxa and 398 across environmental settings. Hence, although some techniques may have been compared 399 using the same metric in several studies, conclusions might differ from one study to another. 400 For instance, in some studies greater fish diversity was recorded with BRUV than with DOV 401 (Langlois et al., 2010), TOWV and SRUV (Watson et al., 2005), and UVC (Willis and 402 Babcock, 2000), while others show that more fish species were detected with UVC than with 403 BRUV (Tessier et al., 2005; Langlois et al., 2006; Stobart et al., 2007; Colton and Swearer, 404 2010; Lowry et al., 2012) and DOV (Greene and Alevizon, 1989; Pelletier et al., 2011). In 405 general, differences in observed abundances between techniques also depend on taxa 406 (Watson et al., 2010; Pelletier et al., 2011), thereby determining distinct observed assemblage structures (Table 8).

408 Directly comparing techniques in the field is rather difficult in that observations may be 409 influenced by many factors, either natural or linked to fine-scale system deployment. Paired 410 observations are needed to control for observation conditions, such as time of the day, 411 weather, and the precise observation location. But since implementation in the field may 412 depend on the technique, the number of observations that can be carried out within a given 413 time period, as well as the habitat and depth constraints, may also differ from one technique 414 to another. Thus, a paired comparison may only address the issue of comparing two 415 observations of the same seascape and species, and not the actual advantages and 416 shortcomings of each technique, and therefore not all facets of their complementarity. 
For comparisons involving a diver-based technique, i.e. UVC or DOV vs TOWV, RUV or

418 BRUV, the main differences between techniques were due to the presence of divers. The 419 influence of divers' presence on UVC observations has been widely documented (Chapman 420 et al., 1974; Harmelin-Vivien et al., 1985; Kulbicki, 1998; Dearden et al., 2010). UVC also 421 raise a number of additional issues such as the need for species identification skills, the 422 variability of observations between divers, and the influence of swimming speed (Brock, 423 1982; Bell et al., 1985; Lincoln-Smith, 1988; Kulbicki et al., 2010; Dickens et al., 2011). In the 424 case of diver-free video observations, the factors inherent in each technique, that may affect 425 observations, have not been evaluated from specifically designed studies. These include, for 426 instance, the bait plume or noise, the use of artificial light, and more generally the behaviour 427 of animals with respect to the video system. In addition, the area actually surveyed by each 428 technique inevitably affects the number of species and individuals detected.

Hence, many factors can explain differences between observations obtained from 430 distinct techniques. Because not all these factors can be controlled, it is important to bear 431 them in mind when interpreting the outcomes of comparisons.

432 From the published studies, no single technique clearly appears to outperform the 433 others; although some are more appropriate for particular purposes. Thus RUV appeared as 434 an appropriate diver-free observation technique, as it can be left in place for a long time, at a 435 range of depths, and in low light conditions when using additional lights (see Supplementary 436 material B, C and D for detailed outcomes of the comparisons in Table 8). It can be used to 437 investigate areas, parameters and factors that cannot be observed from techniques relying 438 on divers, and it enables a high level of temporal and spatial replication. RUV was often 439 found appropriate for surveying common and conspicuous species. BRUV was found 440 particularly appropriate for sampling generalist carnivores, large predators and mobile 441 species. Because it relies on attracting species, it may be usefully deployed in areas when 442 fish are scarce, e.g. pelagic areas or sandy substrates in lagoon areas. The main advantage 443 of TOWV lies in its ability to sample a large area in a short period of time, thereby increasing 444 the spatial coverage of habitats, and the probability of observing species, including rare 
445 species (although motile species may be sensitive to boat noise). DOV was deemed 446 adequate for studies at smaller scales, e.g. to study changes in corals, gorgonians and 447 macro-algae, and to provide representative observations of fish abundance and species 448 diversity. The various techniques should thus be seen as providing complementary 449 standpoints on shallow biodiversity and species.

\subsection{Cost-efficiency considerations}

In addition to the information provided by each kind of observation, investment and operating costs are crucial parameters when considering an observation technique. Overall,

454 few papers documented implementation costs for the techniques used, whereas the time required for image analysis is often seen as a shortcoming of underwater video techniques.

456 Francour et al. (1999) found that underwater video was more cost-efficient than UVC in 457 terms of total time spent in the field and in the laboratory. Based on a subset of papers, 458 Murphy and Jenkins (2010) found that relative costs were AUD\$1,000-5,000 for RUV and 459 AUD\$5,000-10,000 for BRUV. However, financial costs are difficult to evaluate for a given 460 technique, because of the various ways of manufacturing systems, and because of 461 differences in the characteristics of the camcorders and sensors used. It is thus more 462 relevant to compare required staff time rather than financial costs of equipment. Note also 463 that time spent at sea is always more expensive than laboratory time (Pelletier et al., 2011; 464 Bernard and Gotz, 2012). The cost-efficiency of several observation techniques were 465 compared by Leujak and Ormond (2007) (six techniques for surveying coral communities) 466 and by Langlois et al. (2010) (stereo-BRUV versus stereo-DOV transects for observing fish 467 assemblages) (Table 9). Pelletier et al. $(2011,2012)$ detailed observation costs (including 468 both field and image analysis) for DOV and ROT-RUV, with respect to UVC.

469 Cost-efficiency considerations must account for the fact that a technique which is better 470 at observing or detecting species, either because of attraction (BRUV) or because of a higher 471 image resolution, will inevitably require increased time for image analysis. For example, 472 Bernard and Götz (2012) found that a BRUV station required 7 hours of staff time versus 3.5 
473 hours for RUV, but this was mostly due to the fact that BRUV detected more species and

474 individuals than RUV (Table 9). Consequently, a larger time for post-field analysis should not 475 be considered as a weakness if higher diagnostic power is the end result (Bernard and Gotz, 476 2012).

\section{Underwater video in the light of current monitoring challenges}

As mentioned in the introduction, conservation objectives and sustainable management of coastal biodiversity and resources involve monitoring the status of several biodiversity components in large areas. This is the case for MPA assessment and for regional or global conservation agendas. Present global commitments to reduce biodiversity loss entail setting up MPAs in most regions of the world. MPAs are not only more numerous, but also larger, and how they achieve conservation objectives must be assessed. Consistently with MPA conservation objectives (Pelletier, 2011), monitoring and assessment should include fish and macroinvertebrate resources, but also fixed fauna, essential habitats, and protected or emblematic species. Maintaining the diversity of taxa and the functioning of species assemblage are additional conservation objectives. Yet, biodiversity is rarely observed and assessed on large spatial scales due to observation costs.

Underwater video may help in making good some of these monitoring gaps. Three main questions are generally raised by the use of video techniques for observing and monitoring 492 biodiversity, species and habitat in shallow waters: i) how much does it cost?; ii) is image analysis (i.e. identifying and counting species) an issue?; and iii) what are the observation 494 area and the required duration of observations? Cost-efficiency questions were addressed in subsection 4.2 when comparing video techniques. Issues ii) and iii) are addressed below in 496 subsections 5.1 and 5.2. We will then discuss the two main advantages of most underwater 497 video techniques: their non-obtrusive nature and the potential for high replication 498 (subsections 5.3 and 5.4). Finally, we will compare the advantages and shortcomings of observation techniques in subsection 5.5. 
5.1 Is image analysis an issue?

502 The issue of image analysis is often raised by the use of video, in particular the ability to 503 identify and count species, along with the time required to do this. Underwater visibility is a 504 limitation for all visual techniques, whether UVC, video or photo. However, divers conducting 505 UVC or DOV may compensate for reduced visibility by moving toward the observation target. 506 Moreover, the larger the observation surface area, the more critical the visibility. In this 507 respect, RUV may be more dependent upon visibility than BRUV which attracts species 508 closer to the camcorder. High Definition was not always used in recent studies, yet we 509 believe it substantially improves the quality of the resulting data at little extra cost. Being able 510 to take time to identify and count, including the possibility of consulting identification books or 511 experts is actually convenient. Because video footage is archived, it may be shared and 512 analysed independently, thereby enabling discussion about identifications and cross513 validation of image analyses. In addition, archiving footage ensures data traceability. 514 Identifying species and counting individuals from two-dimensional images may be initially 515 challenging to people trained in other techniques, but most people learn to do so within a 516 month or two.

517 The second issue concerns the time needed for image analysis. From our experience, the 518 post-treatment of images balances the time gained in the field through diver-based visual 519 techniques (Pelletier et al., 2011, 2012). This required time may vary depending on the kind 520 of information extracted, e.g. the list of taxa studied, and on the experience of the observer. 521 But it is mostly dependent upon the abundance and species richness in the observation area, 522 which should not be seen as a drawback (see end of section 4).

\subsection{Observation area and duration}

Video techniques exhibit large differences in terms of information provided. First, 526 observed surface areas are not all the same. Horizontal RUV enables observed surfaces and 527 distances to be estimated through horizontal vision, in a similar way to UVC. However, the 528 accuracy and precision of these estimates, whether from RUV or from UVC, should not be 
neglected. Delineation of the observed surface area (e.g. from strip transects) or mark setting

530 to standardize surveyed areas is possible, but inevitably increases observation duration and 531 may influence observations, because it requires divers. Stereo-video makes it possible to 532 precisely estimate the observation distance and the size of observed individuals, which are 533 otherwise visually estimated either from post-field image analysis (RUV, TOWV, non stereo534 BRUV, DOV) or underwater (UVC). For such visual estimations, training from silhouettes has 535 proved useful (Thompson and Mapstone, 1997; N. Guilpart, D. Mallet, D. Pelletier, 536 unpublished data). For vertically-oriented systems (TOWV or RUV), the observed surface 537 may be estimated based on lens and zoom parameters, provided that the camera elevation 538 above the floor is controlled and known. In the particular case of BRUV, the unknown bait 539 plume prevents the evaluation of the actual surface concerned by the observation.

540 Regarding observation duration, BRUV is constrained by effective bait attraction, which 541 needs a minimum amount of time, from 25 to 40 minutes (Willis and Babcock, 2000; Watson 542 et al., 2007, Bernard and Gotz, 2012). TOWV allows continuous recording of images along 543 the vessel trajectory and footage is often subsampled for image analysis (see references in 544 Table 3). The duration of a single RUV observation varies from a few minutes to an hour (see 545 references in Table 5), depending on the study objective and the system characteristics.

5.3. Non-obtrusive observations of species assemblages?

Underwater video techniques provide direct observations of species in their natural 549 habitat, and they are not extractive. Diver-free video techniques are also less intrusive than 550 UVC (see section 1 for references). Among these, TOWV may disturb the ecosystem 551 through vessel noise, though this can be circumvented by using appropriate engines. BRUV 552 data rely on bait attraction within an unknown distance around the observation system. In this 553 respect, observations resemble fishing data, as they are selective, depending on both 554 species and bait. The effect of bait composition and size on catch was well studied (Salia et 555 al., 2002; Smith, 2002; Lowry et al., 2006; Alos et al., 2009; Dorman et al., 2012), as was the 556 behaviour of species near baited fishing gear (e.g. in deep environment: Craig et al., 2005) or 
near fishery discards (Hill and Wassenberg, 2000). But the distance and range of attraction

558 of vagile fauna by the bait is difficult to test, and to our knowledge, no such study was 559 published at the time of the review. Regarding (unbaited) RUV, our own experience indicates 560 that while some fish already present nearby may be curious when a system is first set up, 561 they rapidly resume their normal behaviour, and the video system does not seem to attract 562 distant fish (D. Mallet and D. Pelletier, unpublished data).

\section{5.4. Temporal and spatial replication}

565 With the exception of DOV, for which the number of observations that can be carried out per day is limited by diver's presence (although DOV is quicker than UVC in the field), a large amount of data may be collected per day, making it possible to accomplish highly spatially and temporally replicated designs. Most RUV techniques were indeed designed to be set for

569 a long time and to provide information on behaviour, diurnal rhythms and species activity 570 over long periods of undisturbed observation. This enables an array of questions to be 571 addressed that cannot be studied by other observation techniques. The ability of video 572 systems to produce a large number of observations can also be used in a spatial perspective, for instance to investigate changes in macrofauna and population behaviour, 574 and to correlate communities with environmental variables or anthropogenic pressures.

575 Hence, the response of biodiversity to fishing, MPA protection and other impacts of coastal 576 uses may be addressed at relevant scales. Observation designs may be properly replicated 577 with respect to factors influencing the distribution of biodiversity, such as site and habitat on 578 several scales. A high level of replication then enables relationships between biodiversity 579 metrics and environmental variables to be investigated by increasing the statistical power of 580 analyses and diagnostics.

581 Beyond the replication issue, the consistency between data collected in distinct areas by 582 different teams is reinforced by the use of identical systems. Within an ecosystem-based 583 approach to fisheries management, a better understanding of the temporal variations in 584 spatial patterns of biodiversity and resources is needed. In this respect, diver-free techniques 
may at the same time enable small-scale studies with an increased resolution and enlarge the spatial coverage of designs up to the ecosystem scale. For DOV, data consistency is also increased, as there are no differences between videos filmed by distinct divers. Moreover, additional sensors can be coupled to video systems and thus collect additional information on biotic and abiotic variables, as recently advocated by Johnson et al. (2013).

\subsection{Which technique for observing and monitoring coastal biodiversity?}

The choice of a video technique first depends on the object of the study. Reviewed applications of video techniques in shallow waters were listed in Section 3. These are only a sample of the potential use of each technique, as in this area, technological progress is swift (subsection 2.6) and there is room for innovation and alternative types of implementation. General recommendations may thus be made regarding the scope of each technique (Table 10, last column), but these main features should be seen as indicative rather than prescriptive. For instance, none of the references specifically dealt with the observation of juvenile or larval fish. Yet this could be achieved by several existing RUV techniques, by setting them in appropriate locations with adequate camera settings. Likewise, shy species may be monitored using automated systems regularly recording species activity. Indeed a wide spectrum of applications is feasible with the current technologies.

There are still advantages and shortcomings associated with each technique. These were discussed in the previous subsections (5.1 to 5.4) and summarized in Table 10. Choosing a technique must thus stem from both the general features of each technique and their proven outcomes, but technical adaptations and fast technological changes should also be taken into account. The techniques most often used for observing and monitoring coastal biodiversity and resources remain UVC, fishing and, to a lesser extent, acoustics. This situation prevails for both research studies and management-oriented monitoring. Although not recent, the advent of video techniques has not altered this situation. Indeed, many video systems developed in the past only served during a given research project, and were not intended to be transferred to other contexts or users. This situation changed with the 
613 development of BRUV, where the same technique is now repeatedly used in many different 614 contexts.

615 In the process of selecting a technique for a given study, investment and operating costs 616 are two crucial parameters, particularly when replicated designs involving a large number of 617 observations are envisaged. Although these costs were not often documented in the papers, 618 the review showed that compared to UVC, i) video techniques generally involved less time 619 spent on the field at the expense of more time spent in post-treatment, for image analysis; 620 and ii) a lower level of scientific expertise was required during field work. Other features may 621 vary from one technique to another (see Section 2 for description of techniques).

5.6. Future prospects for underwater video monitoring

The technological progress seen in the last decade (see subsection 2.6) will continue, so that system autonomy, storage capacity, and sensor resolution will increase. Human626 operated systems will continue to be used, particularly for research and in the context of 627 participative management in coastal areas. But there is a wide scope for automated systems. 628 These can be permanent stations with multiple sensors, either cabled (see e.g. ESONET project: http://www.esonet-noe.org/About-ESONET and Aguzzi et al., 2011, 2012) or mobile 630 systems transmitting information, e.g. programmed gliders (Moline and Schofield, 2009). 631 Such advances will considerably increase the amount of data collected by underwater video 632 systems (among other techniques). It will thus be essential to analyse and manage these 633 large data sets. Automated image analysis will be key for gaining time. Several projects have 634 been set up with this objective, see for instance the Fish4Knowledge project, which aims to 635 analyse undersea fish videos (www.Fish4Knowledge.eu, Phoenix et al., 2013). However, 636 species identification and counting not requiring human intervention still remains a challenge. 637 Properly managed data is the second issue, particularly in view of long-term monitoring. 638 Furthermore, data for biodiversity monitoring and assessment are often collected at the scale 639 of an entire ecosystem, and they are to be shared within collaborative projects. Developing 
640 shared protocols and data management utilities for collecting and utilizing the wealth of data

641 that will be made available in the future should be a priority.

642 Global commitments to conservation also entail research issues at larger scales, 643 particularly regarding spatial patterns of biodiversity and ecosystem approaches to 644 management and conservation (Christensen et al., 1996). Hence, for both research and 645 monitoring purposes, observations with improved spatial coverage and resolution should be 646 carried out in all habitats; they should document exploited and non-exploited species, as well 647 as benthic coverage, including sensitive taxa such as sea grass and coral. These 648 considerable information needs cannot be achieved solely through the techniques used so 649 far, and complementary observation techniques are needed, among which video techniques, 650 either on stand-alone basis or preferably combined with other techniques, are definitely a 651 good candidate.

652

\section{Acknowledgements}

654 The authors thank two anonymous reviewers and the editor for their helpful comments on an 655 earlier version of this paper. This work has benefitted from numerous exchanges with 656 colleagues working with video techniques, particularly Trevor Willis, Mike Cappo and Tim 657 Langlois. We also thank Thierry Laugier for comments on an earlier draft of this paper. This 658 work is part of a PhD Thesis jointly funded by the French Institute for the Exploitation of the 659 Sea (IFREMER) and the Agence des Aires Marines Protégées.

660 We are extremely grateful to the various authors and publishers who allowed us to reproduce 661 pictures of their video systems. In order of appearance in the publication:

662 1) the Horizontal Remote Underwater Video system of LaFond et al. (1961) reproduced 663 with the permission of E.C. LaFond, "Photographic problems in oceanography", Underwater 664 Photo-Optical Instrumentation Applications, Seminar Report, SPIE, pp. 11-18. San Diego, 665 California, (1968). 
666 2) the Acoustic Remote Underwater Video system of Kumpf and Lowenstein (1962) 667 reproduced with the permission from H.E. Kumpf and J.M. Lowenstein, "Undersea 668 Observation Station", Sea Frontiers, volume 8, 198-206, (1962).

669 3) the Acoustic Remote Underwater Video system of Stevenson (1967) reproduced with the 670 permission of R.A. Stevenson, "Underwater television", Oceanology Intl, volume 2, 30-35, $671 \quad$ (1967).

672 4) the Horizontal Remote Underwater Video system of Fedra and Machan (1979) 673 reproduced with the permission from Springer, Marine Biology, K. Fedra and R. Machan, "A 674 Self-Contained Underwater Time-Lapse Camera for in situ Long-Term Observations", 675 Marine Biology, volume 55, 239-246, (1979).

676 5) the Vertical Remote Underwater Video system of Stokesbury et al. (2004) and Tyne et 677 al. (2010) reproduced with the permission of Julian A. Tyne, N.R. Loneragan, M. Krützen, 678 S.J. Allen and L. Bejder, "An integrated data management and video system for sampling 679 aquatic benthos”, Marine and Freshwater Research, volume 61, 1023-1028, (2010).

680 6) the Horizontal Remote Underwater Video system of Jan et al. (2007) reproduced with 681 the permission of Dr. Rong-Quen Jan, Yi-Ta Shao, Fang-Pang Lin, Tung-Yung Fan, Yueh682 Yuan Tu, Hsien-Shiow Tsai and Kwang-Tsao Shao, "An underwater camera system for 683 real-time coral reef fish monitoring", The Raffles Bulletin of Zoology, volume 14, 273-279, 684 (2007).

685 7) the Horizontal Baited Remote Underwater Video system of Ellis and DeMartini (1995) 686 reproduced with the permission from the U.S government, D. Ellis and E. DeMartini, 687 "Evaluation of a video camera technique for indexing abundances of juvenile pink snapper, 688 Pristipomoides filamentosus, and other Hawaiian insular shelf fishes", Fisheries Bulletin, 689 volume 93, 67-77, (1995).

690 8) the vertical Baited Remote Underwater Video system of Willis and Babcock (2000) 691 reproduced with the permission of Marine and Freshwater Research 51(8), 755-763 (Trevor 692 J. Willis and Russell C. Babcock). Copyright CSIRO 2000. Published by CSIRO 
694 http://www.publish.csiro.au/nid/126/paper/MF00010.htm.

695 9) the Mid-water Horizontal Baited Remote Underwater Video system of Heagney et al. 696 (2007) reproduced with the permission from E.C. Heagney, T.P. Lynch, R.C. Babcock and 697 I.M. Suthers, "Pelagic fish assemblages assessed using mid-water baited video: 698 standardising fish counts using bait plume size", Marine Ecology Progress Series, Volume $699350,255-266,(2007)$.

10) the Seabed Towed Video system of Machan and Fedra (1975) reproduced with the 701 permission from Springer, Marine Biology, R. Machan and K. Fedra, "A New Towed Underwater Camera System for Wide-Range Benthic Surveys”, Marine Biology, volume 33, 75-84, (1975).

11) the Seabed Towed Video system of Holme and Barrett (1977) reproduced with the permission of N.A. Holme and R.L. Barrett, "A sledge with television and photographic cameras for quantitative investigation of the epifauna on the continental shelf", Journal of the Marine Biological Association of the United Kingdom, Volume 57, 391-403, (1977).

12) the Mid-water Towed Video system of Riegl et al. (2001) reproduced with the permission of B. Riegl, J.L. Korrubel and C. Martin, "Mapping and monitoring of coral communities and their spatial patterns using a surface-based video method from a vessel", Bulletin of Marine 711 Science, Volume 69, 869-880, (2001).

712 13) the Seabed Towed Video system of Spencer et al. (2005) reproduced with the 713 permission of Mara L. Spencer, A.W. Stoner, C.H. Ruer, J.E. Munk, "A towed camera for 714 estimating abundance of juvenile flatfishes and habitat characteristics: Comparison with 715 beam trawls and divers", Estuarine, Coastal and Shelf Science, volume 64, 497-503, 716 (2005).

717 14) the Seabed Towed Video system of Rooper and Zimmermann (2007) reproduced with 718 the permission from Karna McKinney, Alaska Fisheries Science Center, NOAA Fisheries. 


\section{References}

720 Aguzzi, J., Company, J.B., Costa, C., Matabos, M., Azzurro, E., Manuel, A., Menesatti, P., 721 Sarda, F., Canals, M., Delory, E., Cline, D., Favali, P., Juniper, S.K., Furushima, Y., 722 Fujiwara, Y., Chiesa, J.J., Marotta, L., Bahamon, N., Priede, I.G., 2012. Challenges to assessment of benthic populations and biodiversity as a result of rhythmic behaviour:

724 Video solutions from cabled observatories, in: Gibson, R.N., Atkinson, R.J.A., Gordon, 725 J.D.M., Hughes, R.N. (Eds.), Oceanography and Marine Biology: An Annual Review, Vol $726 \quad 50$, pp. 235-285.

727 Aguzzi, J., Manuel, A., Condal, F., Guillen, J., Nogueras, M., del Rio, J., Costa, C., 728 Menesatti, P., Puig, P., Sarda, F., Toma, D., Palanques, A., 2011. The New Seafloor 729 Observatory (OBSEA) for Remote and Long-Term Coastal Ecosystem Monitoring. Sensors $730 \quad 11,5850-5872$.

731 Alevizon, W.S., Brooks, M.G., 1975. The comparative structure of two Western Atlantic reef732 fish assemblages. Bulletin of Marine Science 25, 482-490.

733 Alos, J., Arlinghaus, R., Palmer, M., March, D., Alvarez, I., 2009. The influence of type of 734 natural bait on fish catches and hooking location in a mixed-species marine recreational 735 fishery, with implications for management. Fisheries Research 97, 270-277.

736 Aronson, R.B., Edmunds, P.J., Precht, W.F., Swanson, D.W., Levitan, D.R., 1994. Large737 scale, long-term monitoring of Caribbean coral reefs: simple, quick, inexpensive 738 techniques. Atoll Research Bulletin 421, 1-19.

739 Assis, J., Narváez, K., Haroun, R., 2007. Underwater towed video: a useful tool to rapidly 740 assess elasmobranch populations in large marine protected areas. Journal of Coastal 741 Conservation 11, 153-157.

742 Babcock, R.C., Kelly, S., Shears, N.T., Walker, J.W., Willis, T.J., 1999. Changes in 743 community structure in temperate marine reserves. Marine Ecology Progress Series 189, $744 \quad 125-134$.

745 Bacheler, N.M., Schobernd, C.M., Schobernd, Z.H., Mitchell, W.A., Berrane, D.J., Kellison, 746 G.T., Reichert, M.J.M., 2013. Comparison of trap and underwater video gears for indexing 
reef fish presence and abundance in the southeast United States. Fisheries Research 143, $748 \quad 81-88$

749 Backus, R.H., Barnes, H., 1957. Television-echo sounder observations of midwater sound 750 scatterers. Deep-Sea Research 4, 116-119.

751 Barans, C.A., Arendt, M.D., Moore, T., Schmidt, D., 2005. Remote video revisited: A visual 752 technique for conducting long-term monitoring of reef fishes on the continental shelf. 753 Marine Technology Society Journal 39, 110-118.

754 Barans, C.A., Schmidt, D., Brouwer, M.C., 2002. Potential for coupling of underwater TV 755 monitoring with passive acoustics, in: Rountree, R., Goudey, C., Hawkins, T., Luczkovich, 756 J.J., Mann, D. (Eds.), Listening to Fish: Proceedings of the International Workshop on the 757 Applications of Passive Acoustics to Fisheries. Massachusetts Institute of Technology 758 Cambridge, USA, p. 172.

759 Barnes, H., 1952. Under-water television and marine biology. Nature 169, 477-479.

760 Barnes, H., 1953. Underwater television and research in marine biology, bottom topography 761 and geology. I. A description of the equipment and its use on board ship. Deutsche 762 Hydrographische Zeitschrift 6, 123-133.

763 Barnes, H., 1955. Underwater television and research in marine biology, bottom topography 764 and geology. II. Experience with the equipment. Deutsche Hydrographische Zeitschrift 8, $765 \quad 213-236$.

766 Barnes, H.B., 1963. Underwater television. Oceanography and Marine Biology: An Annual 767 Review 11, 115-128.

768 Bassett, D.K., Montgomery, J.C., 2011. Investigating nocturnal fish populations in situ using 769 baited underwater video: With special reference to their olfactory capabilities. Journal of $770 \quad$ Experimental Marine Biology and Ecology 409, 194-199.

771 Becker, A., Cowley, P.D., Whitfield, A.K., 2010. Use of remote underwater video to record 772 littoral habitat use by fish within a temporarily closed South African estuary. Journal of $773 \quad$ Experimental Marine Biology and Ecology 391, $161-168$. 
774 Bell JD, Craik GJS, Pollard DA, Russell BC (1985) Estimating length frequency distributions 775 of large reef fish underwater. Coral Reefs 4:41 - 44

776 Bellwood, D.R., Fulton, C.J., 2008. Sediment-mediated suppression of herbivory on coral 777 reefs: decreasing resilience to rising sea levels and climate change? Limnology and 778 Oceanography 53, 2695-2701.

779 Bellwood, D.R., Hoey, A.S., Choat, J.H., 2003. Limited functional redundancy in high 780 diversity systems: resilience and ecosystem function on coral reefs. Ecology Letters 6, $781 \quad 281-285$.

782 Bellwood, D.R., Hughes, T.P., Hoey, A.S., 2006. Sleeping functional group drives coral-reef 783 recovery. Current Biology 16, 2434-2439.

784 Bennett, S., Bellwood, D.R., 2011. Latitudinal variation in macroalgal consumption by fishes 785 on the Great Barrier Reef. Marine Ecology Progress Series 426, 241-U269.

786 Bernard, A.T.F., Götz , A., 2012. Bait increases the precision in count data from remote 787 underwater video for most subtidal reef fish in the warm-temperate Agulhas bioregion. 788 Marine Ecology Progress Series 471, 235-252.

789 Birt, M.J., Harvey, E.S., Langlois, T.J., 2012. Within and between day variability in temperate 790 reef fish assemblages: Learned response to baited video. Journal of Experimental Marine $791 \quad$ Biology and Ecology 416-417, 92-100.

792 Bloomfield, H.J., Sweeting, C.J., Mill, A.C., Stead, S.M., Polunin, N.V.C., 2012. No-trawl 793 area impacts: perceptions, compliance and fish abundances. Environmental Conservation $794 \quad 39,237-247$.

795 Bohnsack, J.A., Bannerot, S.P., 1986. A Stationary Visual Census Technique for 796 Quantitatively Assessing Community Structure of Coral Reef Fishes. NOAA Technical 797 Report NMFS 41, 1-15.

798 Bond, M.E., Babcock, E.A., Pikitch, E.K., Abercrombie, D.L., Lamb, N.F., Chapman, D.D., 799 2012. Reef Sharks Exhibit Site-Fidelity and Higher Relative Abundance in Marine $800 \quad$ Reserves on the Mesoamerican Barrier Reef. PLoS ONE 7.

801 Booda, L.L., 1966. Industry bees swarm at NEL. UnderSea Technology 7, 23-25. 
802 Bortone, S.A., Martin, T., Bundrick, C.M., 1991. Visual census of reef fish assemblages: A 803 comparison of slate, audio, and video recording devices. Northeast Gulf Science 12, 17-23. 804 Bortone, S.A., Martin, T., Bundrick, C.M., 1994. Factors Affecting Fish Assemblage 805 Development on a Modular Artificial Reef in a Northern Gulf of Mexico Estuary. Bulletin of $806 \quad$ Marine Science 55, 319-332.

807 Bräger, S., Chong, A., Dawson, S., Slooten, E., Würsig, B., 1999. A combined stereo808 photogrammetry and underwater-video system to study group composition of dolphins. 809 Helgoland Marine Research 53, 122-128.

810 Brock, R.E., 1982. A critique of the visual census method for assessing coral reef fish 811 populations. Bulletin of Marine Science 32, 269-276.

812 Brock, V.E., 1954. A preliminary report on a method of estimating reef fish population. 813 Journal of Wildlife Management 18, 297-308.

814 Bucas, M., Daunys, D., Olenin, S., 2007. Overgrowth patterns of the red algae Furcellaria 815 lumbricalis at an exposed Baltic Sea coast: The results of a remote underwater video data 816 analysis. Estuarine, Coastal and Shelf Science 75, 308-316.

817 Buhl-Mortensen, L., Buhl-Mortensen, P., Dolan, M.F.J., Dannheim, J., Bellec, V., Holte, B., 818 2012. Habitat complexity and bottom fauna composition at different scales on the 819 continental shelf and slope of northern Norway. Hydrobiologia 685, 191-219.

820 Burge, E.J., Atack, J.D., Andrews, C., Binder, B.M., Hart, Z.D., Wood, A.C., Bohrer, L.E., 821 Jagannathan, K., 2012. Underwater Video Monitoring of Groupers and the Associated 822 Hard-Bottom Reef Fish Assemblage of North Carolina Bulletin of Marine Science 88, 15$823 \quad 38$.

824 Burkepile, D.E., Hay, M.E., 2011. Feeding complementarity versus redundancy among 825 herbivorous fishes on a Caribbean reef. Coral Reefs 30, 251-362.

826 Burrows, M.T., Kawai, K., Hughes, R.N., 1999. Foraging by mobile predators on a rocky 827 shore: under- water TV observations of movements of blennies Lipophrys pholis and crabs 828 Carcinus maenas. Marine Ecology Progress Series 187, 237-250. 
829 Cappo, M., De'ath, G., Speare, P., 2007a. Inter-reef vertebrate communities of the Great 830 Barrier Reef Marine Park determined by baited remote underwater video stations. Marine 831 Ecology Progress Series 350, 209-221.

832 Cappo, M., Harvey, E., Malcolm, H., Speare, P., 2003. Potential of video techniques to 833 monitor diversity, abundance and size of fish in studies of marine protected areas, in: 834 Beumer, J.P., Grant, A., Smith, D.C. (Eds.), APAC Congress 2002: Aquatic protected 835 areas - What works best and how do we know ? World Congress on Aquatic Protected 836 Areas proceedings. National Library of Australia, Cairns,Qld, Australia, pp. 455 - 464.

837 Cappo, M., Harvey, E., Shortis, M., 2007b. Counting and measuring fish with baited video 838 techniques - an overview, in: Lyle, J.M., Furlani, D.M., Buxton, C.D. (Eds.), Proceedings of 839 the 2006 Australian Society of Fish Biology Conference and Workshop Cuttingedge 840 Technologies in Fish and Fisheries Science, Hobart, August 2006, pp. 101-114.

841 Cappo, M., Speare, P., De'ath, G., 2004. Comparison of baited remote underwater video 842 stations (BRUVS) and prawn (shrimp) trawls for assessments of fish biodiversity in inter843 reefal areas of the Great Barrier Reef Marine Park. Journal of Experimental Marine Biology 844 and Ecology 302 123-152.

845 Cappo, M., Stowar, M., Syms, C., Johansson, C., Cooper, T., 2011. Fish-habitat 846 associations in the region offshore from James Price Point - a rapid assessment using 847 Baited Remote Underwater Video Stations (BRUVS). Journal of the Royal Society of $848 \quad$ Western Australia 94, 303-321.

849 Carbines, G., Cole, R.G., 2009. Using a remote drift underwater video (DUV) to examine 850 dredge impacts on demersal fishes and benthic habitat complexity in Foveaux Strait, 851 Southern New Zealand. Fisheries Research 96 230-237.

852 Carleton, J.H., Done, T.J., 1995. Quantitative video sampling of coral reef benthos: large853 scale application Coral Reefs 14, 35-46.

854 Chabanet, P., Loiseau, N., Join, J.-L., Ponton, D., 2012. VideoSolo, an autonomous video 855 system for high-frequency monitoring of aquatic biota, applied to coral reef fishes in the 
856 Glorioso Islands (SWIO). Journal of Experimental Marine Biology and Ecology 430-431, $857 \quad 10-16$.

858 Chapman, C.J., Johnstone, A.D.F., Dunn, J.R., Creasey, D.J., 1974. Reactions of Fish to 859 Sound Generated by Divers' Open-Circuit Underwater Breathing Apparatus. Marine $860 \quad$ Biology 27, 357-366.

861 Chatfield, B.S., Van Niel, K.P., Kendrick, G.A., Harvey, E.S., 2010. Combining 862 environmental gradients to explain and predict the structure of demersal fish distributions. 863 Journal of Biogeography 37, 593-605.

864 Christensen, N.L., Bartuska, A.M., Brown, J.H., Carpenter, S., Dantonio, C., Francis, R., 865 Franklin, J.F., MacMahon, J.A., Noss, R.F., Parsons, D.J., Peterson, C.H., Turner, M.G., 866 Woodmansee, R.G., 1996. The report of the ecological society of America committee on 867 the scientific basis for ecosystem management. Ecological Applications 6, 665-691.

868 Colin, P.L., 1971. Interspecific Relationships of the Yellowhead Jawfish, Opistognathus 869 aurifrons (Prisce, Opistognathidae). Copeia 1971, 469-473.

870 Colin, P.L., 1972. Daily Activity Patterns and Effects of Environmental Conditions on the 871 Behavior of the yellowhead Jawfish, Opistognathus aurifons with Notes on its Ecology. $872 \quad$ Zoologica, N. Y. 57, 137-169.

873 Colin, P.L., 1973. Burrowing Behavior of the yellowhead Jawfish, Opistognathus aurifrons. 874 Copeia 1973, 84-90.

875 Colton, M.A., Swearer, S.E., 2010. A comparison of two survey methods: differences 876 between underwater visual census and baited remote underwater video. Marine Ecology 877 Progress Series 400, 19-36.

878 Condal, F., Aguzzi, J., Sarda, F., Nogueras, M., Cadena, J., Costa, C., Del Rio, J., Manuel, 879 A., 2012. Seasonal rhythm in a Mediterranean coastal fish community as monitored by a $880 \quad$ cabled observatory. Marine Biology 159, 2809-2817.

881 Cooke, S.J., Schreer, J.F., 2002. Determination of fish community composition in the 882 untempered regions of a thermal effluent canal - The efficacy of a fixed underwater 883 videography system. Environmental Monitoring and Assessment 73, 109-129. 
884 Craig, S.R., Stoner, A.W., Matterson, K., 2005. Use of high-frequency imaging sonar to 885 observe fish behaviour near baited fishing gears. Fisheries Research 76, 291-304.

886 Cruz, I.C.S., kikushi, R.K.P., Leão, Z.M.A.N., 2008. Use of the video transect method for 887 characterizing the Itacolomis reefs, eastern Brazil. Brazilian Journal of Oceanography 56, $888 \quad 271-280$.

889 Cummings, W.C., Brahy, B.D., Spires, J.Y., 1966. Sounds production, schooling, and 890 feeding habits of the margate, Haemulon album Cuvier, off North Bimini, Bahamas. Bulletin 891 of Marine Science 16, 626-640.

892 Cvitanovic, C., Bellwood, D.R., 2009. Local variation in herbivore feeding activity on an $893 \quad$ inshore reef of the Great Barrier Reef. Coral Reefs 28.

894 Davis, G.E., Anderson, T.W., 1989. Population estimates of four kelp forest fishes and an 895 evaluation of three in situ assessment techniques. Bulletin of Marine Science 44, 11388961151.

897 Dearden, P., Theberge, M., Yasué, M., 2010. Using underwater cameras to assess the 898 effects of snorkeler and SCUBA diver presence on coral reef fish abundance, family 899 richness, and species composition. Environmental Monitoring and Assessment 163, 531$900 \quad 538$.

901 Delcourt, J., Denoël, M., Ylieff, M., Poncin, P., 2012. Video multitracking of fish behaviour: a 902 synthesis and future perspectives. Fish and Fisheries, online 2 MAR 2012.

903 Dendrinos, P., Tounta, E., Karamanlidis, A.A., Legakis, A., Kotomatas, S., 2007. A Video 904 Surveillance System for Monitoring the Endangered Mediterranean Monk Seal (Monachus 905 monachus). Aquatic Mammals 33, 179-184.

906 Denny, C.M., Babcock, R.C., 2004. Do partial marine reserves protect reef fish 907 assemblages? Biological Conservation 116, $119-129$.

908 Denny, C.M., Willis, T.J., Babcock, R.C., 2004. Rapid recolonisation of snapper Pagrus 909 auratus: Sparidae within an offshore island marine reserve after implementation of no-take 910 status. Marine Ecology Progress Series 272, $183-190$. 
911 Dickens, L.C., Goatley, C.H.R., Tanner, J.K., Bellwood, D.R., 2011. Quantifying Relative 912 Diver Effects in Underwater Visual Censuses. PLoS ONE 6, e18965.

913 Dorman, S.R., Havrey, E.S., Newman, S.J., 2012. Bait Effects in Sampling Coral Reef Fish 914 Assemblages with Stereo-BRUVs. PLoS ONE 7, e41538.

915 Dunbrack, R.L., 2006. In situ measurement of fish body length using perspective-based 916 remote stereo-video. Fisheries Research 82, 327-331.

917 Dunbrack, R.L., 2008. Abundance trends for Hexanchus griseus, Bluntnose Sixgill Shark, 918 and Hydrolagus colliei, Spotted Ratfish, counted at an automated underwater observation 919 station in the Strait of Georgia, British Columbia. Canadian Field-Naturalist 122, 124-128.

920 Dunbrack, R.L., Zielinski, R., 2003. Seasonal and diurnal activity of sixgill sharks 921 (Hexanchus griseus) on a shallow water reef in the Strait of Georgia, British Columbia. 922 Canadian Journal of Zoology 81, 1107-1111.

923 Dunlap, M., Pawlik, J.R., 1996. Video-monitored predation by Caribbean reef fishes on an 924 array of mangrove and reef sponges. Marine Biology 126, 117-123.

925 Ellis, D., DeMartini, E., 1995. Evaluation of a video camera technique for indexing 926 abundances of juvenile pink snapper, Pristipomoides filamentosus, and other Hawaiian 927 insular shelf fishes. Fishery Bulletin 93, 67-77.

928 Enstipp, M.R., Gremillet, D., Jones, D.R., 2007. Investigating the functional link between 929 prey abundance and seabird predatory performance. Marine Ecology Progress Series 331, $930 \quad 267-279$.

931 Fedra, K., Machan, R., 1979. A Self-Contained Underwater Time-Lapse Camera for in situ 932 Long-Term observations. Marine Biology 55, 239-246.

933 Fernandes, L., 1990. Effect of the distribution and density of benthic target organisms on 934 manta tow estimates of their abundance Coral Reefs 9, 161-165.

935 Fischer, P., Weber, A., Heine, G., Weber, H., 2007. Habitat structure and fish: assessing the 936 role of habitat complexity for fish using a small, semiportable, 3-D underwater observatory. 937 Limnology and Oceanography: Methods 5, 250-262. 
938 Fitzpatrick, B.M., Harvey, E.S., Heyward, A.J., Twiggs, E.J., Colquhoun, J., 2012. Habitat 939 Specialization in Tropical Continental Shelf Demersal Fish Assemblages. PLoS ONE 7.

940 Fox, R.J., Bellwood, D.R., 2007. Quantifying herbivory across a coral reef depth gradient.

$941 \quad$ Marine Ecology Progress Series 339, 49-59.

942 Fox, R.J., Bellwood, D.R., 2008a. Direct versus indirect methods of quantifying herbivore 943 grazing impact on a coral reef. Marine Biology 154, 325-334.

944 Fox, R.J., Bellwood, D.R., 2008b. Remote video bioassays reveal the potential feeding 945 impact of the rabbitfish Siganus canaliculatus (f: Siganidae) on an inner-shelf reef of the 946 Great Barrier Reef Coral Reefs 27, 605-615.

947 Francour, P., Liret, C., Harvey, E., 1999. Comparison of fish abundance estimates made by 948 remote underwater video and visual census. Naturalista Sicil 23, $155-168$.

949 Gladstone, W., Lindfield, S., Coleman, M., Kelaher, B., 2012. Optimisation of baited remote 950 underwater video sampling designs for estuarine fish assemblages. Journal of 951 Experimental Marine Biology and Ecology 429, 28-35.

952 Gledhill, C.T., Lyczkowski-Shultz, J., Rademacher, K., Kargard, E., Crist, G., Grace, M.A., 953 1996. Evaluation of video and acoustic index methods for assessing reef-fish populations. 954 Journal of Marine Science 53, 483-485.

955 Göetze, J.S., Langlois, T.J., Egli, D.P., Harvey, E.S., 2011. Evidence of artisanal fishing 956 impacts and depth refuge in assemblages of Fijian reef fish. Coral Reefs 30, 1-11.

957 Gomelyuk, V.E., 2009. Fish assemblages composition and structure in three shallow 958 habitats in north Australian tropical bay, Garig Gunak Barlu National Park, Northern 959 Territory, Australia. J Mar Biol Assoc Uk 89, 449-460.

960 Grabowski, T.B., Boswell, K.M., McAdam, B.J., Wells, R.J.D., Marteinsdottir, G., 2012. 961 Characterization of Atlantic Cod Spawning Habitat and Behavior in Icelandic Coastal $962 \quad$ Waters. PLoS ONE 7.

963 Greene, L.E., Alevizon, W.S., 1989. Comparative accuracies of visual assessment methods 964 for coral reef fishes. Bulletin of Marine Science 44, 899 - 912. 
965 Grizzle, R.E., Brodeur, M.A., Abeels, H.A., Greene, J.K., 2008. Bottom habitat mapping 966 using towed underwater videography: subtidal oyster reefs as an example application. 967 Journal of Coastal Research 24, 103-109.

968 Hall, K.C., Hanlon, R.T., 2002. Principal features of the mating system of a large spawning 969 aggregation of the giant Australian cuttlefish Sepia apama (Mollusca : Cephalopoda). $970 \quad$ Marine Biology 140, 533-545.

971 Handley, S., Kelly, S., Kelly, M., 2003. Non-destructive video image analysis method for 972 measuring growth in sponge farming: preliminary results from the New Zealand bath973 sponge Spongia (Heterofibria) manipulatus. New Zealand Journal of Marine and 974 Freshwater Research 37, 613-621.

975 Hannah, R.W., Jones, S.A., 2012. Evaluating the behavioral impairment of escaping fish can 976 help measure the effectiveness of bycatch reduction devices. Fisheries Research 131, 3997744.

978 Harmelin-Vivien, M.L., Harmelin, J.G., Chauvet, C., Duval, C., Galzin, R., Lejeune, P., 979 Barnabé, G., Blanc, F., Chevalier, R., Duclerc, J., Lasserre, G., 1985. The underwater 980 observation of fish communities and fish populations: Methods and problems. Revue 981 d'Ecologie (Terre Vie) 40:44, 467-539.

982 Harvey, E., Cappo, M., Shortis, M., Robson, S., Buchanan, J., Speare, P., 2003. The 983 accuracy and precision of underwater measurements of length and maximum body depth 984 of southern bluefin tuna (Thunnus maccoyii) with a stereo-video camera system. Fisheries $985 \quad$ Research 63, 315-326.

986 Harvey, E., Fletcher, D., Shortis, M., 2001a. A comparison of the precision and accuracy of 987 estimates of reef-fish lengths determined visually by divers with estimates produced by a 988 stereo-video system. Fisheries Bulletin 99, 63-71.

989 Harvey, E., Fletcher, D., Shortis, M., 2001b. Improving the statistical power of visual length 990 estimates of reef fish: a comparison of divers and stereo-video. Fisheries Bulletin 99, 72 99180. 
992 Harvey, E., Fletcher, D., Shortis, M., 2002a. Estimation of reef fish length by divers and by 993 stereo-video. A first comparison of the accuracy and precision in the field on living fish 994 under operational conditions. Fisheries Research 57, 255-265.

995 Harvey, E., Fletcher, D., Shortis, M.R., Kendrick, G.A., 2004. A comparison of underwater 996 visual distance estimates made by scuba divers and a stereo-video system : implications 997 for underwater visual census of reef fish abundance. Marine and Freshwater Research 55, $998 \quad 573-580$.

999 Harvey, E., Shortis, M., 1995. A system for Stereo-Video Measurement of Sub-Tidal 1000 organisms. Marine Technology Society Journal 29, 10-22.

1001 Harvey, E., Shortis, M., Stadler, M., Cappo, M., 2002b. A comparison of the accuracy and 1002 precision of measurements from single and stereo-video systems. Marine Technology 1003 Society Journal 36, 38-49.

1004 Harvey, E.S., Butler, J.J., McLean, D.L., Shand, J., 2012a. Contrasting habitat use of diurnal 1005 and nocturnal fish assemblages in temperate Western Australia. Journal of Experimental 1006 Marine Biology and Ecology 426, 78-86.

1007 Harvey, E.S., Cappo, M., Butler, J.J., Hall, N., Kendrick, G.A., 2007. Bait attraction affects 1008 the performance of remote underwater video stations in assessment of demersal fish 1009 community structure. Marine Ecology Progress Series 350, 245-254.

1010 Harvey, E.S., Dorman, S.R., Fitzpatrick, C., Newman, S.J., McLean, D.L., 2012b. Response 1011 of diurnal and nocturnal coral reef fish to protection from fishing: an assessment using 1012 baited remote underwater video. Coral Reefs 31, 939-950.

1013 Harvey, E.S., Newman, S.J., McLean, D.L., Cappo, M., Meeuwig, J.J., Skeeper, C.L., 2012c. 1014 Comparison of the relative efficiencies of stereo-BRUVs and traps for sampling tropical 1015 continental shelf demersal fishes. Fisheries Research 125-126, 108-120.

1016 Harvey, E.S., Shortis, M.R., 1998. Calibration Stability of an Underwater Stereo Video 1017 System: Implications for Measurement Accuracy and Precision. Marine Technology 1018 Society Journal 32, $3-17$. 
1019 Hayashizaki, K.-i., Ogawa, H., 2006. Introduction of underwater video system for the 1020 observation of coastal macroalgal vegetation. Coastal Marine Science 30, 196-200.

1021 Heagney, E.C., Lynch, T.P., Babcock, R.C., Suthers, I.M., 2007. Pelagic fish assemblages 1022 assessed using mid-water baited video: standardising fish counts using bait plume size. 1023 Marine Ecology Progress Series 350, 255-266.

1024 Heppell, S.A., Semmens, B.X., Archer, S.K., Pattengill-Semmens, C.V., Bush, P.G., McCoy, 1025 C.M., Heppell, S.S., Johnson, B.C., 2012. Documenting recovery of a spawning 1026 aggregation through size frequency analysis from underwater laser calipers 1027 measurements. Biological Conservation 155, 119-127.

1028 Hill, B.J., Wassenberg, T.J., 2000. The probable fate of discards from prawn trawlers fishing 1029 near coral reefs: A study in the northern Great Barrier Reef, Australia. Fisheries Research $1030 \quad 48,277-286$.

1031 Hoey, A.S., 2010. Size matters: macroalgal height influences the feeding response of coral 1032 reef herbivores. Marine Ecology Progress Series 411, 299-U341.

1033 Hoey, A.S., Bellwood, D.R., 2009. Limited Functional Redundancy in a High Diversity 1034 System: Single Species Dominates Key Ecological Process on Coral Reefs. Ecosystems $1035 \quad 12,1316-1328$.

1036 Hoey, A.S., Bellwood, D.R., 2010. Cross-shelf variation in browsing intensity on the Great 1037 Barrier Reef. Coral Reefs 29, 499-508.

1038 Hoey, A.S., Bellwood, D.R., 2011. Suppression of herbivory by macroalgal density: a critical 1039 feedback on coral reefs? Ecology Letters 14, 267-273.

1040 Holme, N.A., Barrett, R.L., 1977. A sledge with television and photographic cameras for 1041 quantitative investigation of the epifauna on the continental shelf. J Mar Biol Assoc Uk 57, $1042 \quad 391-403$.

1043 Holt, D., 1967. opportunities for research utilizing underwater TV and acoustic systems. 1044 BioScience 17, 635-636. 
1045 Houk, P., Van Woesik, R., 2006. Coral Reef Benthic Video Surveys Facilitate Long-Term

1046 Monitoring in the Commonwealth of the Northern Mariana Islands: Toward an Optimal 1047 Sampling Strategy. Pacific Science 60, 177-189.

1048 Jan, R.-Q., Shao, Y.-T., Lin, F.-P., Fan, T.-Y., Tu, Y.-Y., Tsai, H.-S., Shao, K.-T., 2007. An

1049 underwater camera system for real-time coral reef fish monitoring. The Raffles Bulletin of 1050 Zoology 14, 273-279

1051 Jenkins, S.R., Mullen, C., Brand, A.R., 2004. Predator and scavenger aggregation to 1052 discarded by-catch from dredge fisheries: importance of damage level. Journal of Sea 1053 Research 51, 69-76.

1054 Jones, D.T., Wilson, C.D., Robertis, A.D., Rooper, C.N., Weber, T.C., Butler, J.L., 2012. 1055 Evaluation of rockfish abundance in untrawlable habitat: combining acoustic and 1056 complementary sampling tools. Fisheries Bulletin 110, 332-343.

1057 Johnson AF, Jenkins SR, Hiddink JG, Hinz H (2013) Linking temperate demersal fish 1058 species to habitat: scales, patterns and future directions. Fish and Fisheries 14:256-280

1059 Jouffre, D., Borges, M.d.F., Bundy, A., Coll, M., Diallo, I., Fulton, E.A., Guitton, J., Labrosse, 1060 P., Abdellahi, K.o.M., Masumbuko, B., Thiao, D., 2010. Estimating EAF indicators from 1061 scientific trawl surveys: theorical and pratical concerns. Journal of Marine Science 67, 7961062806.

1063 Kenyon, J.C., Brainard, R.E., Hoeke, R.K., Parrish, F.A., Wilkinson, C.B., 2006. Towed-Diver 1064 Surveys, a Method for Mesoscale Spatial Assessment of Benthic Reef Habitat: A Case 1065 Study at Midway Atoll in the Hawaiian Archipelago. Coastal Management 34, 339-349.

1066 Krohn, M.M., Boisclair, D., 1994. Use of a stereo-video system to estimate the energy 1067 expenditure of free swimming fish. Canadian Journal of Aquatic and Fisheries Science 51, $1068 \quad 1119-1127$.

1069 Kronengold, M., Dann, R., Green, W.C., Loewenstein, J.M., 1964. An acoustic-video system 1070 for marine biological research : description of the system, in: Tavolga, W.N. (Ed.), Marine 1071 Bio-acoustics. Pergamon Press, New York, pp. 47-57. 
1072 Kulbicki, M., 1998. How the acquired behaviour of commercial reef fishes may influence the

1073 results obtained from visual censuses. Journal of Experimental Marine Biology and 1074 Ecology 222, 11-30.

1075 Kulbicki, M., Cornuet, N., Vigliola, L., Wantiez, L., Moutham, G., Chabanet, P., 2010. 1076 Counting coral reef fishes: Interaction between fish life-history traits and transect design. 1077 Journal of Experimental Marine Biology and Ecology 387, 15-23.

1078 Kumpf, H.E., 1964. Use of underwater television in bio-acoustic research, in: Tavolga, W.N. 1079 (Ed.), Marine Bio-Acoustics. Pergamon Press, New York, pp. 47-57.

1080 Kumpf, H.E., Lowenstein, J.M., 1962. Undersea Observation Station. Sea Frontiers 8, 198206.

1082 LaFond, E.C., 1968. Photographic problems in oceanography, Underwater Photo-Optical 1083 Instrumentation Applications, Seminar Report, SPIE, San Diego, California, pp. 11-18.

1084 LaFond, E.C., Barham, E.G., Armstrong, W.H., 1961. Use of underwater television in 1085 oceanographic studies of a shallow-water marine environment - Research and 1086 Development Report. U.S. Navy Electronics Laboratory, San Diego, California, p. 32.

1087 Lam, K., Shin, P.K.S., Bradbeer, R., Randall, D., Ku, K.K.K., Hodgson, P., Cheung, S.G., 1088 2006. A comparison of video and point intercept transect methods for monitoring 1089 subtropical coral communities. Journal of Experimental Marine Biology and Ecology 333, $1090 \quad 115-128$.

1091 Langlois, T., Chabanet, P., Pelletier, D., Harvey, E., 2006. Baited underwater video for 1092 assessing reef fish populations in marine reserves, Secretariat of the South Pacific 1093 Community Fisheries Newsletter, pp. 53-56.

1094 Langlois, T.J., Fitzpatrick, B.R., Fairclough, D.V., Wakefield, C.B., Hesp, S.A., McLean, D.L., 1095 Harvey, E.S., Meeuwig, J.J., 2012a. Similarities between Line Fishing and Baited Stereo1096 Video Estimations of Length-Frequency: Novel Application of Kernel Density Estimates. $1097 \quad$ PLoS ONE 7, e45973. 
1098 Langlois, T.J., Harvey, E.S., Fitzpatrick, B., Meeuwig, J.J., Shedrawi, G., Watson, D.L., 1099 2010. Cost-efficient sampling of fish assemblages: comparison of baited video stations and 1100 diver video transects. Aquatic Biology 9, 155-168.

1101 Langlois, T.J., Harvey, E.S., Meeuwig, J.J., 2012b. Strong direct and inconsistent indirect 1102 effects of fishing found using stereo-video: Testing indicators from fisheries closures. $1103 \quad$ Ecological Indicators 23, 524-534.

1104 Lefèvre, C.D., Bellwood, D.R., 2011. Temporal variation in coral reef ecosystem processes: 1105 herbivory of macroalgae by fishes. Marine Ecology Progress Series 422, 239-251.

1106 Leonard, G.H., Clark, R.P., 1993. Point quadrat versus video transect estimates of the cover 1107 of benthic red algae. Marine Ecology Progress Series 101, 203-208.

1108 Leujak, W., Ormond, R.F.G., 2007. Comparative accuracy and efficiency of six coral 1109 community survey methods. Journal of Experimental Marine Biology and Ecology 351, 168 $1110-187$.

1111 Lincoln-Smith, M.P., 1988. Effects of observer swimming speed on sample counts of 1112 temperate rocky reef fish assemblages. Marine Ecology Progress Series 43, 223 - 231.

1113 Longo, G.O., Floeter, S.R., 2012. Comparison of remote video and diver's direct 1114 observations to quantify reef fishes feeding on benthos in coral and rocky reefs. Journal of $1115 \quad$ Fish Biology 81, 1773-1780.

1116 Lowry, M., Folpp, H., Gregson, M., 2011. Evaluation of an underwater solid state memory 1117 video system with application to fish abundance and diversity studies in south east 1118 Australia. Fisheries Research 110, 10-17.

1119 Lowry, M., Folpp, H., Gregson, M., Suthers, I., 2012. Comparison of baited remote 1120 underwater video (BRUV) and underwater visual census (UVC) for assessment of artificial 1121 reefs in estuaries. Journal of Experimental Marine Biology and Ecology 416-417, 243-253.

1122 Lowry, M., Steffe, A., Williams, D., 2006. Relationships between bait collection, bait type and 1123 catch: A comparison of the NSW trailer-boat and gamefish-tournament fisheries. Fisheries $1124 \quad$ Research 78, 266-275. 

Benthic Surveys. Marine Biology 33, 75-84.

Malcolm, H.A., Gladstone, W., Lindfield, S., Wraith, J., Lynch, T.P., 2007. Spatial and temporal variation in reef fish assemblages of marine parks in New South Wales, Australia—baited video observations. Marine Ecology Progress Series 350, 277-290.

Mallet, D., Wantiez, L., Lemouellic, S., Vigliola, L., Pelletier, D., 2014. Complementarity of rotating video and underwater visual census for assessing species richness, frequency and density of reef fish on coral reef slopes. PLoS ONE 9, e84344.

1134 herbivorous coral reef fishes. Coral Reefs 26, 435-442.

1135 Mantyka, C.S., Bellwood, D.R., 2007b. Macroalgal grazing selectivity among herbivorous coral reef fishes. Marine Ecology Progress Series 352, 177-185.

1137 Martinez, I., Jones, E.G., Davie, S.L., Neat, F.C., Wigham, B.D., Priede, I.G., 2011. 1138 Variability in behaviour of four fish species attracted to baited underwater cameras in the 1139 North Sea Hydrobiologia 670, 23-34.

1140 Masuda, R., Matsuda, K., Tanaka, M., 2012. Laboratory video recordings and underwater 1141 visual observations combined to reveal activity rhythm of red-spotted grouper and banded 1142 wrasse, and their natural assemblages. Environmental Biology of Fishes 95, 335-346.

1143 McCauley, D.J., McLean, K.A., Bauer, J., Young, H.S., Micheli, F., 2012. Evaluating the 1144 performance of methods for estimating the abundance of rapidly declining coastal shark 1145 populations. Ecological Applications 22, 385-392.

1146 McDonald, J.I., Coupland, G.T., Kendrick, G.A., 2006. Underwater video as a monitoring tool 1147 to detect change in seagrass cover. Journal of Environmental Management 80, $148-155$. 1148 McLean, D.L., Harvey, E.S., Fairclough, D.V., Newman, S.J., 2010. Large decline in the 1149 abundance of a targeted tropical lethrinid in areas open and closed to fishing. Marine $1150 \quad$ Ecology Progress Series 418, 189-199. 
1151 McLean, D.L., Harvey, E.S., Meeuwig, J.J., 2011. Declines in the abundance of coral trout

1152 (Plectropomus leopardus) in areas closed to fishing at the Houtman Abrolhos Islands,

1153 Western Australia. Journal of Experimental Marine Biology and Ecology 406, 71-78.

1154 Meynecke, J.-O., Poole, G.C., Werry, J., Lee, S.Y., 2008. Use of PIT tag and underwater

1155 video recording in assessing estuarine fish movement in a high intertidal mangrove and

1156 salt marsh creek. Estuarine, Coastal and Shelf Science 79, 168-178.

1157 Michalopoulos, C., Auster, P.J., Malatesta, R.J., 1992. A comparison of transect and 1158 species-time counts for assessing faunal abundance from video surveys. Marine 1159 Technology Society Journal 26, 27-31.

1160 Moline, M.A., Schofield, O., 2009. Remote Real-Time Video-Enabled Docking for

1161 Underwater Autonomous Platforms. Journal of Atmospheric and Oceanis Technology 26, $1162 \quad 2665-2672$.

1163 Monk, J., lerodiaconou, D., Harvey, E., Rattray, A., Versace, V.L., 2012. Are We Predicting 1164 the Actual or Apparent Distribution of Temperate Marine Fishes? PLoS ONE 7.

1165 Morrison, M., Carbines, G., 2006. Estimating the abundance and size structure of an 1166 estuarine population of the sparid Pagrus auratus, using a towed camera during nocturnal 1167 periods of inactivity, and comparisons with conventional sampling techniques. Fisheries $1168 \quad$ Research 82, $150-161$.

1169 Murphy, H.M., Jenkins, G.P., 2010. Observational methods used in marine spatial 1170 monitoring of fishes and associated habitats: a review. Marine and Freshwater Research $1171 \quad 61,236-252$.

1172 Myrberg, A.A., 1972a. Social dominance and territoriality in the bicolor damselfish, 1173 Eupomacentrus partitus (Poey) (Pisces: Pomacentridae). Behaviour 41, 207-231.

1174 Myrberg, A.A., 1972b. Using sound to influence the behaviour of free-ranging maruine 1175 animals, in: Winn, H.E., Olla, B.L. (Eds.), Behavior of marine animals-Current perspectives 1176 in research. PLenum Press, New York, pp. 435-468.

1177 Myrberg, A.A., 1973. Underwater television-a tool for the marine biologist. Bulletin of Marine 1178 Science 23, 825-836. 
1179 Myrberg, A.A., Banner, A., Richard, J.D., 1969. Shark attraction using a video-acoustic $1180 \quad$ system. Marine Biology 2, 264-276.

1181 Myrberg, A.A., Spires, J.Y., 1972. Sound discrimination by the bicolor damselfish, 1182 Eupomacentrus partitus. Journal of Experimental Biology 57, 727-735.

1183 Ninio, R., Delean, S., Osborne, K., Sweatman, H., 2003. Estimating cover of benthic 1184 organisms from underwater video images: variability associated with multiple observers. 1185 marine Ecology Progress Series 265, 107-116.

1186 Ninio, R., Meekan, M., Done, T., Sweatman, H., 2000. Temporal patterns in coral 1187 assemblages on the Great Barrier Reef from local to large spatial scales. Marine Ecology $1188 \quad$ Progress Series 194, 65-74.

1189 Norris, J.G., Wyllie-Echeverria, S., Mumford, T., Bailey, A., Turner, T., 1997. Estimating 1190 basal area coverage of subtidal seagrass beds using underwater videography. Aquatic $1191 \quad$ Botany 58, 269-287.

1192 Parker, R.O., Chester, A.J., Nelson, R.S., 1994. A video transect method for estimating reef 1193 fish abundance, composition, and habitat utilization at Gray's Reef National Marine 1194 Sanctuary, Georgia. Fishery bulletin 92, 787-799.

1195 Pelletier, D., 1991. Les sources d'incertitude en gestion des pêcheries: Evaluation et 1196 propagation dans les modèles. Institut National Agronomique Paris-Grignon, p275.

1197 Pelletier, D., 2011. Constructing and validating indicators of MPA effectiveness, in: Claudet, 1198 J. (Ed.), Marine Protected Areas: Effects, networks and monitoring - A multidisciplinary 1199 approach. Cambridge University Press, pp. 247-289.

1200 Pelletier, D., Leleu, K., Mallet, D., Mou-Tham, G., Hervé, G., Boureau, M., Guilpart, N., 2012. 1201 Remote High-Definition Rotating Video Enables Fast Spatial Survey of Marine Underwater 1202 Macrofauna and Habitats. PLoS ONE 7, e30536.

1203 Pelletier, D., Leleu, K., Mou-Tham, G., Guillemot, N., Chabanet, P., 2011. Comparison of 1204 visual census and high definition video transects for monitoring coral reef fish 1205 assemblages. Fisheries Research 107, 84 - 93. 
1206 Petitgas, P., Cotter, J., Trenkel, V., Mesnil, B., 2009. Fish stock assessments using surveys

1207 and indicators. Aquatic Living Resources 22, 119-119.

1208 Petrell, R.J., Shi, X., Ward, R.K., Naiberg, A., Savage, C.R., 1997. Determining fish size and 1209 swimming speed in cages and tanks using simple video techniques. Aquacultural $1210 \quad$ Engineering 16, 63-84.

1211 Phoenix, X.H., Boom, B.J., Fisher, R.B., 2013. Underwater Live Fish Recognition Using a 1212 Balance-Guaranteed Optimized Tree, in: Lee, K.M., Matsushita, Y., Rehg, J.M., Hu, Z. 1213 (Eds.), Computer Vision -ACCV 2012,11th Asian Conference on Computer Vision 1214 Daejeon, Korea, November 5-9, 2012. Revised Selected Papers, Part I: 422-433., pp. 4221215433.

1216 Picciulin, M., Sebastianutto, L., Codarin, A., Farina, A., Ferrero, E.A., 2010. In situ 1217 behavioural responses to boat noise exposure of Gobius cruentatus (Gmelin, 1789

1218 Richard, J.D., 1968. Fish Attraction with Pulsed Low-Frequency Sound. Journal of Fisheries 1219 Research Board of Canada 25, 1441-1452.

1220 Riegl, B., Korrubel, J.L., Martin, C., 2001. Mapping and monitoring of coral communities and 1221 their spatial patterns using a surface-based video method from a vessel. Bulletin of Marine 1222 Science 69, 869-880.

1223 Robertson, D.R., Smith-Vaniz, W.F., 2008. Rotenone: An Essential but Demonized Tool for 1224 Assessing Marine Fish Diversity. BioScience 58, 165-170.

1225 Rogers, C.S., Miller, J., 2001. Coral bleaching, hurricane damage, and benthic cover on 1226 coral reefs in St. John, U.S. Virgin Islands: A comparison of surveys with the chain transect 1227 method and videography Bulletin of Marine Science 69, 459-470.

1228 Rooper, C.N., Zimmermann, M., 2007. A bottom-up methodology for integrating underwater 1229 video and acoustic mapping for seafloor substrate classification. Continental Shelf $1230 \quad$ Research 27, 947-957.

1231 Rosenkranz, G.E., Byersdorfer, S.C., 2004. Video scallop survey in the eastern Gulf of 1232 Alaska, USA. Fisheries Research 69, 131-140. 
1233 Sale, P.F., 1980. Assemblages of fish on patch reefs - predictable or unpredictable? 1234 Environmental Biology of Fishes 5, 243 - 249.

1235 Salia, S.B., Nixon, S.W., Oviatt, C.A., 2002. Does lobster trap bait influence the Maine 1236 inshore trap fishery? North American Journal of Fisheries Management 22, 602-605.

1237 Sarradin, P.M., Sarrazin, J., Allais, A.G., Almeida, D., Brandou, V., Boetius, A., Buffier, E., 1238 Coiras, E., Colaco, A., Comack, A., Dentrecolas, S., Desbruyeres, D., Dorval, P., du Buf, 1239 H., Dupont, J., Godfroy, A., Gouillou, M., Gronemann, J., Hamel, G., Hamon, M., Hoge, U., 1240 Lane, D., Le Gall, C., Leroux, D., Legrand, J., Leon, P., Leveque, J.P., Masson, M., Olu, 1241 K., Pascoal, A., Sauter, E., Sanfilippo, L., Savino, E., Sebastiao, L., Santos, R.S., Shillito, 1242 B., Simeoni, P., Schultz, A., Sudreau, J.P., Taylor, P., Vuillemin, R., Waldmann, C., 1243 Wenzhoefer, F., Zal, F., 2007. EXtreme ecosystem studies in the deep OCEan: 1244 Technological developments. Oceans 2007 - Europe, New York.

1245 Schaner, T., Fox, M.G., Taraborelli, A.C., 2009. An Inexpensive System for Underwater 1246 Video Surveys of Demersal Fishes. Journal of Great Lakes Research 35, 317-319.

1247 Schobernd, Z.H., Bacheler, N.M., Conn, P.B., 2013. Examining the utility of alternative video 1248 monitoring metrics for indexing reef fish abundance. Journal canadien des sciences 1249 halieutiques et aquatiques (doi: 0.1139/cjfas-2013-0086).

1250 Schultz, A.L., Malcolm, H.A., Bucher, D.J., Smith, S.D.A., 2012. Effects of Reef Proximity on 1251 the Structure of Fish Assemblages of Unconsolidated Substrata. PLoS ONE 7.

1252 Shortis, M.R., Seager, J.W., Williams, A., Barker, B.A., Sherlock, M., 2009. Using stereo1253 video for deep water benthic habitat surveys. Society Journal 42, 28-37.

1254 Shucksmith, R., Hinz, H., Bergmann, M., Kaiser, M.J., 2006. Evaluation of habitat use by 1255 adult plaice (Pleuronectes platessa L.) using underwater video survey techniques. Journal 1256 of Sea Research 56, 317-328.

1257 Smith, C.J., Banks, A.C., Papadopoulou, K.-N., 2007. Improving the quantitative estimation 1258 of trawling impacts from sidescan-sonar and underwater-video imagery. ICES Journal of 1259 Marine Science 64, 1692-1701. 
1260 Smith, C.L., Tyler, J.C., 1973. Population ecology of a Bahamian suprabenthic shore fish 1261 assemblage. American Museum novitates 2528, 37p.

1262 Smith, P.A., 2002. The relationship between stock and catch and the effect of bait on catch 1263 as determined for a UK recreational catch and release fishery. Fisheries Management and 1264 Ecology 9, 261-266.

1265 Spencer, M.L., Stoner, A.W., Ryer, C.H., Munk, J.E., 2005. A towed camera sled for 1266 estimating abundance of juvenile flatfishes and habitat characteristics: Comparison with 1267 beam trawls and divers. Estuarine, Coastal and Shelf Science 64, 497 - 503.

1268 Steinberg, J.C., Cummings, W.C., Brahy, B.D., MacBain Spires, J.Y., 1965. Further Bio1269 Acoustic Studies off the West Coast of North Bimini, Bahamas Bulletin of Marine Science $1270 \quad 15,942-963$.

1271 Steinberg, J.C., Koczy, F.F., 1964. An acoustic-video system for marine biological research : 1272 Objectives and requirements, in: Tavolga, W.N. (Ed.), Marine Bio-acoustics. Pergamon 1273 Press, New York, pp. 1-9.

1274 Stevenson, R.A., 1967. Underwater television. Oceanology International 2, 30-35.

1275 Stevenson, R.A., Myrberg, A.A., 1966. Behavior of the bicolor damselfish, Eupomacentrus 1276 partitus, in the field and in the aquarium. American Society of zoologists 6, 516.

1277 Stobart, B., García-Charton, J.A., Espejo, C., Rochel, E., Goñi, R., Reñones, O., Herrero, A., 1278 Crec'hriou, R., Polti, S., Marcos, C., Planes, S., Pérez-Ruzafa, A., 2007. A baited 1279 underwater video technique to assess shallow-water Mediterranean fish assemblages: 1280 Methodological evaluation. Journal of Experimental Marine Biology and Ecology 345 158$1281 \quad 174$.

1282 Stokesbury, K.D.E., harris, B., P., Marino, M.C., Nogueira, J.I., 2004. Estimation of sea 1283 scallop abundance using a video survey in off-shore US waters. Journal of Shellfish 1284 Research 23, 33-40.

1285 Stoner, A.W., Laurel, B.J., Hurst, T.P., 2008. Using a baited camera to assess relative 1286 abundance of juvenile Pacific cod: Field and laboratory trials. Journal of Experimental 1287 Marine Biology and Ecology 254, 202-211. 
1288 Tessier, E., 2005. Dynamique des peuplements ichtyologiques associés aux récifs artificiels 1289 à l'île de la Réunion (ouest de l'océan Indien) - Implication dans la gestion des pêcheries 1290 côtières., Ecologie Marine. Université de la Réunion, p. 254.

1291 Tessier, E., Chabanet, P., Pothin, K., Soriae, M., Lasserre, G., 2005. Visual censuses of 1292 tropical fish aggregations on artificial reefs: slate versus video recording techniques. 1293 Journal of Experimental Marine Biology and Ecology 315 17-30.

1294 Thompson, A.A., Mapstone, B.D., 1997. Observer effects and training in underwater visual 1295 surveys of reef fishes Marine Ecology Progress Series 154, 53-63.

1296 Thresher, R.E., Gunn, J.S., 1986. Comparative analysis of visual census techniques for 1297 highly mobile, reef associated piscivores (carangidae). Environmental Biology of Fishes 17, 1298 93-116.

1299 Tilot, V., Leujak, W., Ormond, R.F.G., Ashworth, J.A., Mabrouk, A., 2008. Monitoring of 1300 South Sinai coral reefs: influence of natural and anthropogenic factors. Aquatic 1301 Conservation: Marine and Freshwater Ecosystems 18, 1109-1126.

1302 Trenkel, V.M., Cotter, J., 2009. Choosing survey time series for populations as part of an 1303 ecosystem approach to fishery management. Aquatique Living Resources 22, 121-126.

1304 Trenkel, V.M., Ressler, P.H., Jech, M., Giannoulaki, M., Taylor, C., 2011. Underwater 1305 acoustics for ecosystem-based management: state of the science and proposals for 1306 ecosystem indicators. Marine Ecology-Progress Series 442, 285-301.

1307 Tyne, J.A., Loneragan, N.R., Krützen, M., Allen, S.J., Bejder, L., 2010. An integrated data 1308 management and video system for sampling aquatic benthos. Marine and Freshwater $1309 \quad$ Research 61, 1023-1028.

1310 Vergés, A., Bennett, S., Bellwood, D., 2012. Diversity among macroalgae-consuming fishes 1311 in coral reefs: a transcontinental comparison. PLoS ONE 7, e45543.

1312 Vogt, H., Montebon, A.R.F., Alcala, M.L.R., 1997. Underwater video sampling: an effective 1313 method for coral reef surveys?, in: Lessios, H.A., Macintyre, I.G. (Eds.), Proceedings of the 1314 8th International Coral Reef Symposium Vol. 2, Smithsonian Tropical Research Institute, 1315 Panama, pp. 1447-1452. 
1316 Watson, D.L., Anderson, M.J., Kendrick, G.A., Nardi, K., Harvey, E.S., 2009. Effects of 1317 protection from fishing on the lengths of targeted and non-targeted fish species at the 1318 Houtman Abrolhos Islands, Western Australia. Marine Ecology Progress Series 384, 241249.

1320 Watson, D.L., Harvey, E.S., 2007. Behaviour of temperate and sub-tropical reef fishes 1321 towards a stationary SCUBA diver. Marine and Freshwater Behaviour and Physiology 40, 1322 85-103.

1323 Watson, D.L., Harvey, E.S., Anderson, M.J., Kendrick, G.A., 2005. A comparison of 1324 temperate reef fish assemblages recorded by three underwater stereo-video techniques. $1325 \quad$ Marine Biology 148, $415-425$.

1326 Watson, D.L., Harvey, E.S., Fitzpatrick, B.M., Langlois, T.J., Shedrawi, G., 2010. Assessing 1327 reef fish assemblage structure: how do different stereo-video techniques compare? Marine $1328 \quad$ Biology 157, $1237-1250$.

1329 Watson, D.L., Harvey, E.S., Kendrick, G.A., Nardi, K., Anderson, M.J., 2007. Protection from 1330 fishing alters the species composition of fish assemblages in a temperate-tropical transition $1331 \quad$ zone. Marine Biology 152, 1197-1206.

1332 Watson, R.A., Carlos, G.M., Samoilys, M.A., 1995. Bias introduced by the non-random 1333 movement of fish in visual transect surveys. Ecological Modelling 77, 205-214.

1334 Wells, R.J.D., Boswell, K.A., Cowan, J.H., Jr., Patterson, W.F., 2008. Size selectivity of 1335 sampling gears targeting red snapper in the northern Gulf of Mexico. Fisheries Research $1336 \quad 89,294-299$.

1337 Westera, M., Lavery, P., Hyndes, G., 2003. Differences in recreationally targeted fishes 1338 between protected and fished areas of a coral reef marine park. Journal of Experimental 1339 Marine Biology and Ecology 294, 145- 168.

1340 Willis, T.J., 2001. Visual census methods underestimate density and diversity of cryptic reef 1341 fishes. Journal of Fish Biology 59, 1408-1411.

1342 Willis, T.J., Babcock, R.C., 2000. A baited underwater video system for the determination of 1343 relative density of carnivorous reef fish. Marine and Freshwater Research 51, 755-763. 
1344 Willis, T.J., Millar, R.B., 2005. Using marine reserves to estimate fishing mortality. Ecology 1345 Letters 8, 47-52.

1346 Willis, T.J., Millar, R.B., Babcock, R.C., 2000. Detection of spatial variability in relative

1347 density of fishes: comparison of visual census, angling, and baited underwater video.

$1348 \quad$ Marine Ecology Progress Series 198, 249 - 260.

1349 Willis, T.J., Millar, R.B., Babcock, R.C., 2003. Protection of exploited fish in temperate

1350 regions: high density and biomass of snapper Pagrus auratus (Sparidae) in northern New

1351 Zealand marine reserves. Journal of Applied Ecology 40, 214 - 227.

1352 Wraith, J.A., 2007. Assessing reef fish assemblages in a temperate marine park using baited 1353 remote underwater video. University of Wollongong, p. 100.

1354 Young, M.A.L., Bellwood, D.R., 2012. Fish predation on sea urchins on the Great Barrier 1355 Reef. Coral Reefs 31, 731-738. 
Table 1. Technical specifications of unbaited RUV systems. Horizontal $(H)$ and vertical $(\mathrm{V})$ in the second column refer to the direction of image recording.

Source Type Technical details

LaFond et Mounted on a vertical rail

al. (1961) H-RUV Linked to mobile platform

Additional equipment: six floodlights
Illustration

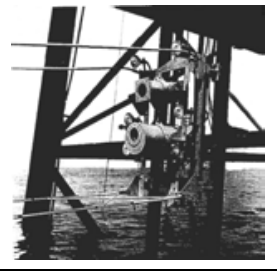

Kumpf and

Lowenstein

(1962);

Kronengold

et al. (1964)

conductor cable.

AC-H-RUV Observation duration: $24 \mathrm{~h}$

Lens view angle: wide

2 spotlights, hydrophones, sound projector

Linked to laboratory control panel

Energy supplied through a submarine cable

Stevenson

(1967);

Holt (1967)

AC-HV-

RUV

Observation duration: $24 \mathrm{~h}$

Pan tilt mechanism $\left(360^{\circ}\right.$ horizontally and $50^{\circ}$

vertically), lens view angle: wide

Remotely controlled windshield-wiper, releasing a toxic material, hydrophones, sound projector

\begin{tabular}{|c|c|c|c|}
\hline $\begin{array}{l}\text { Fedra and } \\
\text { Machan } \\
(1979)\end{array}$ & H-RUV & $\begin{array}{l}\text { Autonomous } \\
\text { Observation duration: } 1 \text { week } \\
\text { Lens view angle: wide } \\
\text { Side flash reflectors ( } 12 \mathrm{~V} \text { battery in separate } \\
\text { housing), Electronic timer ( } 6 \mathrm{~V} \text { batteries) }\end{array}$ & \\
\hline $\begin{array}{l}\text { Dunbrack } \\
\text { and } \\
\text { Zielinski } \\
\text { (2003) }\end{array}$ & V-RUV & $\begin{array}{l}\text { Autonomous } \\
\text { Observation duration: } 240 \mathrm{~h} \text { ( } 20 \text { days) } \\
\text { Black \& white camera, electronic timer } \\
\text { Additional time-lapse video recorder }\end{array}$ & NA \\
\hline $\begin{array}{l}\text { Stokesbury } \\
\text { et al. (2004) } \\
\text { and Tyne et } \\
\text { al. (2010) }\end{array}$ & V-RUV & $\begin{array}{l}\text { Downward-oriented video camera, attached to the } \\
\text { apex of a stainless steel pyramid } \\
\text { Linked to boat } \\
\text { Black \& white camera linked to a laptop computer } \\
\text { Additional infrared illumination }\end{array}$ & \\
\hline $\begin{array}{c}\text { Jan et al. } \\
\text { (2007) }\end{array}$ & H-RUV & $\begin{array}{l}\text { Linked to laboratory, internet video streaming } \\
\text { Continuous recording: } \\
\text { Colour camera } \\
\text { Additional illumination for night time }\end{array}$ & \\
\hline $\begin{array}{l}\text { Aguzzi et } \\
\text { al. (2011); } \\
\text { Condal et } \\
\text { al. (2012) }\end{array}$ & H-RUV & $\begin{array}{l}\text { Linked to laboratory, transmission of audio and video } \\
\text { for internet streaming } \\
\text { Pan tilt mechanism }\left(360^{\circ} \text { horizontally and }{ }^{\circ} 210^{\circ}\right. \\
\text { vertically) }\end{array}$ & $\Delta$ \\
\hline $\begin{array}{l}\text { Pelletier et } \\
\text { al. (2012) }\end{array}$ & $\begin{array}{l}\text { ROT-H- } \\
\text { RUV }\end{array}$ & $\begin{array}{l}2 \text { waterproof housings connected by an axis. } \\
\text { Engine lower housing sets in motion the upper } \\
\text { housing } \\
\text { Programmed rotations of } 60^{\circ} \text { every } 30 \text { seconds } \\
\text { Autonomous } \\
\text { Observation duration: } 9 \text { min (i.e. } 3 \text { rotations) } \\
\text { Colour HD camera, Lens view angle: } 60^{\circ}\end{array}$ & \\
\hline
\end{tabular}


Table 2. Technical specifications of Baited RUV systems. Horizontal $(H)$ and vertical $(\mathrm{V})$ in the second column refer to the direction of image recording.

\section{Source Type Technical details}

\section{illustration}

Autonomous

Set on bottom

Ellis and

DeMartini

(1995)

Observation duration: 10 to $60 \mathrm{~min}$

H-BRUV Colour camera (red filter for underwater vision)

Lens view angle: wide

No additional sensors

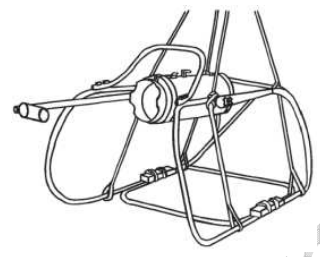

Willis and

Babcock

(2000)

Linked to boat

V-BRUV Observation duration: 30 or $60 \mathrm{~min}$

Colour camera

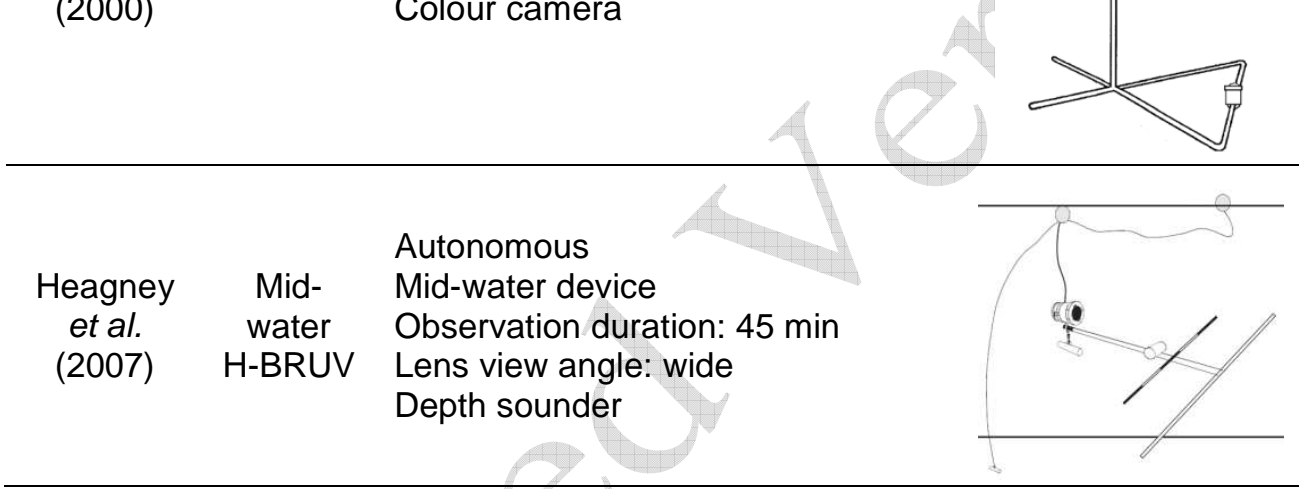


Table 3. Technical specifications of Towed video systems (TOWV). Camera orientation is reported in the third column.

\section{Source Type Technical details}

\section{Illustration}

$\begin{array}{cc}\text { Machan } & \text { Seabed } \\ \text { and Fedra } & \text { TOWV } \\ \text { (1975) } & \end{array}$

Angled down $\left(30^{\circ}\right)$

Linked to boat

Boat speed: $\max 1 \mathrm{~m} . \mathrm{s}^{-1}$

Observation distance: $20 \mathrm{~km}$ in 1 day

Still camera, spotlight, flash

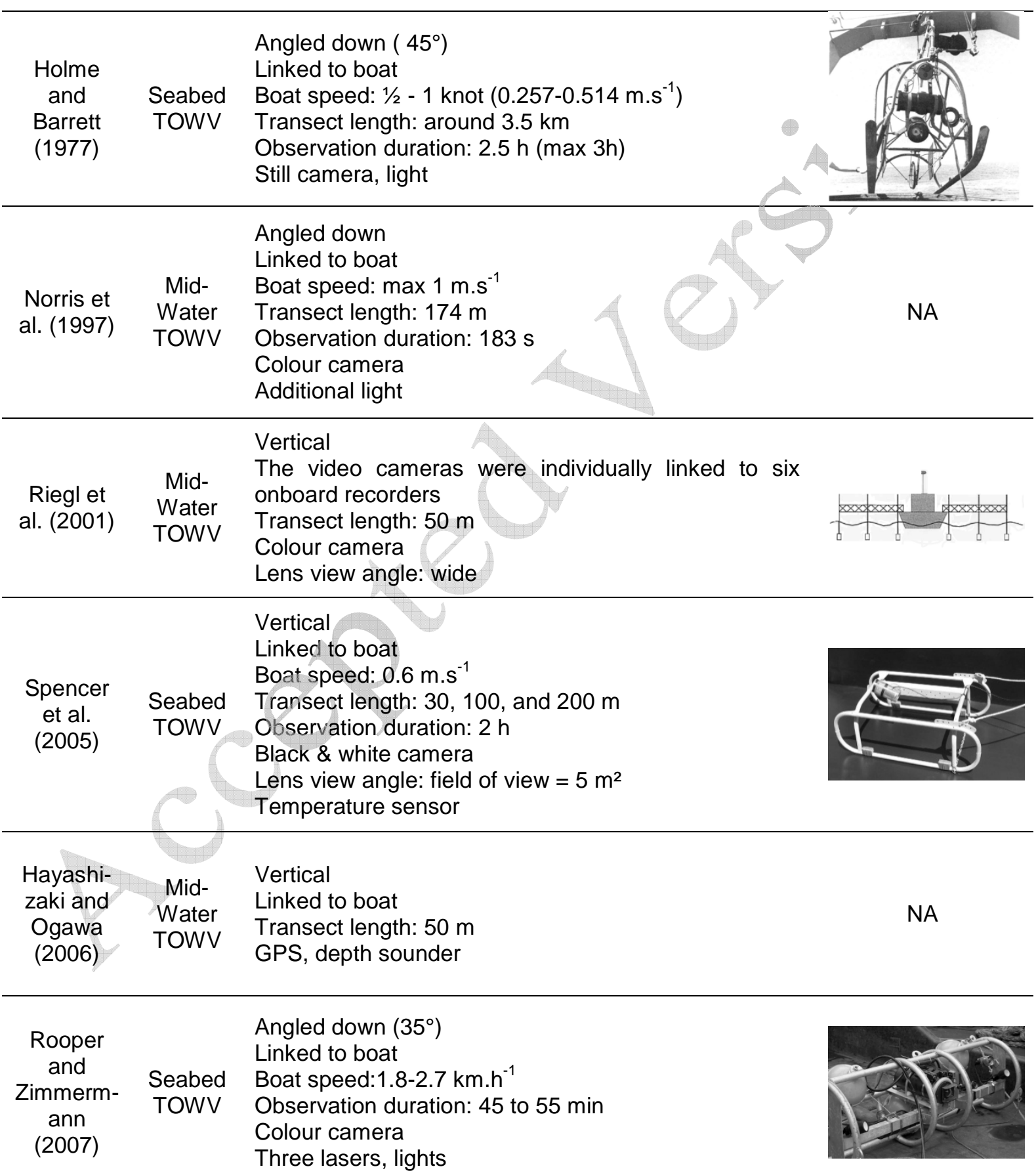


Table 4. Referenced studies involving DOV, with main protocol features, and study focus. For comparison, Bortone et al. $(1991,1994)$ presented the stationary rotating point count technique for counting fish, with an observation radius of $5.64 \mathrm{~m}$ (see text for details). ST: straight transect; TC: time census; TT: towed transect; BT: browsed transect.

\begin{tabular}{|c|c|c|c|c|c|}
\hline Source & $\begin{array}{l}\text { Census } \\
\text { type }\end{array}$ & $\begin{array}{l}\text { Length } \\
\text { (m) }\end{array}$ & $\begin{array}{c}\text { Distance } \\
\text { above the } \\
\text { bottom }(\mathrm{cm})\end{array}$ & $\begin{array}{l}\text { Speed } \\
\left(\mathrm{m}^{-1} \mathrm{~s}^{-1}\right)\end{array}$ & $\begin{array}{l}\text { Study } \\
\text { Fish / } \\
\text { Habitat }\end{array}$ \\
\hline Alevizon and Brooks (1975) & ST & 50 & NA & NA & Fish \\
\hline Davis and Anderson (1989) & ST & 200 & 100 & 0.33 & Fish \\
\hline Greene and Alevizon (1989) & ST & NA & NA & constant & Fish \\
\hline Leonard and Clark (1993) & ST & 2 & 50 & 0.07 & Habitat \\
\hline Aronson et al. (1994) & ST & 25 & NA & slowly & $\begin{array}{l}\text { Fish \& } \\
\text { Habitat }\end{array}$ \\
\hline Parker et al. (1994) & $\begin{array}{c}\text { TC } \\
(15 \mathrm{~min})\end{array}$ & NA & 100 & $\begin{array}{l}\text { with } \\
\text { prevailing } \\
\text { current }\end{array}$ & Fish \\
\hline \multirow{2}{*}{ Carleton and Done (1995) } & TT & 200 & $100-150$ & $1-1.23$ & Habitat \\
\hline & ST & 200 & $100-150$ & $0.63-0.78$ & Habitat \\
\hline Vogt et al. (1997) & TT & 500 & $50-70$ & $0.11-0.25$ & Habitat \\
\hline Ninio et al. (2000) & ST & 50 & $25-30$ & NA & Habitat \\
\hline Rogers and Miller (2001) & ST & $\begin{array}{c}20 \text { and } \\
100\end{array}$ & 40 & 0.03 & Habitat \\
\hline Ninio et al. (2003) & ST & 50 & 25 to 30 & NA & $\begin{array}{l}\text { Fish \& } \\
\text { Habitat }\end{array}$ \\
\hline $\begin{array}{l}\text { Tessier (2005); } \\
\text { Tessier et al. (2005) }\end{array}$ & ST & 24 & 300 & 0.3 & Fish \\
\hline Watson et al. (2005) & ST & 25 & NA & NA & $\begin{array}{l}\text { Fish \& } \\
\text { Habitat }\end{array}$ \\
\hline $\begin{array}{l}\text { Houk and Van Woesik } \\
(2006)\end{array}$ & ST & $\begin{array}{l}15,35 \\
\text { and } 50\end{array}$ & NA & 0.15 & Habitat \\
\hline Kenyon et al. (2006) & TT & $\begin{array}{l}19.2 \text { to } \\
38.6\end{array}$ & 100 & $0.69-0.97$ & Habitat \\
\hline Lam et al. (2006) & ST & 50 & 40 & 0.10 & Habitat \\
\hline Leujak and Ormond (2007) & ST & 50 & $30-35$ & 0.12 & Habitat \\
\hline Cruz et al. (2008) & ST & 20 & 40 & 0.05 & Habitat \\
\hline Langlois et al. (2010) & ST & 25 & 30 & 3 & $\begin{array}{l}\text { Fish \& } \\
\text { Habitat }\end{array}$ \\
\hline Watson et al. (2010) & ST & $\begin{array}{l}50 \text { and } \\
100\end{array}$ & 30 & 0.34 & $\begin{array}{l}\text { Fish \& } \\
\text { Habitat }\end{array}$ \\
\hline \multirow{2}{*}{ Pelletier et al. (2011) } & ST & 50 & 150 & $0.2-0.3$ & Fish \\
\hline & BT & $50 \times 4$ & $\begin{array}{l}\text { varying } \\
\text { elevation }\end{array}$ & speed & Fish \\
\hline
\end{tabular}




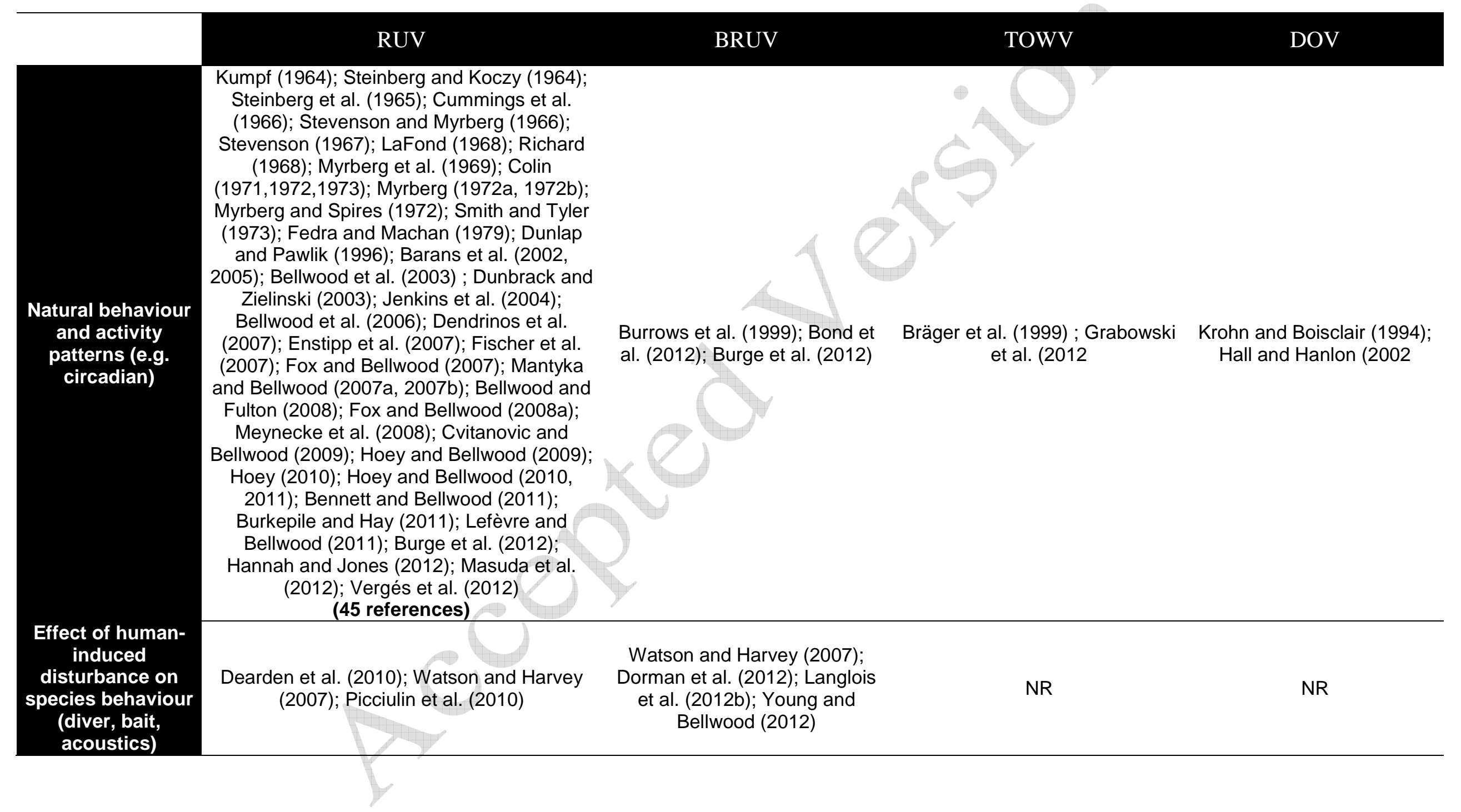


Spatial and temporal patterns

of abundance

size and fish

assemblage

composition

(including effects

of habitat,

anthropogenic

pressures and

protection)

Dunbrack (2008) ; Becker et al. (2010); Aguzzi et al. (2011); Bloomfield et al. (2012); Burge et al. (2012); Chabanet et al. (2012);

Condal et al. (2012); Pelletier et al. (2012)

(8 references)

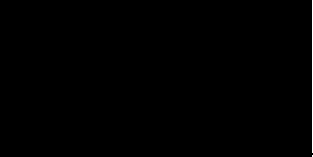

Benthos

abundance and

size monitoring

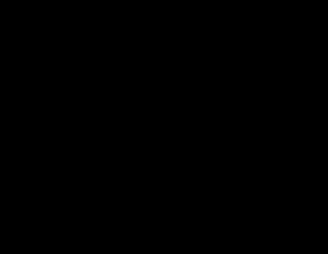

Habitat mapping,

Benthic cover

monitoring and

impact of fishing

gears on habitat
Willis and Babcock (2000)

Willis et al. (2000, 2003); Denny and Babcock (2004); Denny et al. (2004); Cappo et al. (2007a); Malcolm et al. (2007); Stobart et al. (2007); Wraith (2007) Stoner et al. (2008); Gomelyuk (2009); Watson et al. (2009);

Chatfield et al. (2010); McLean et al. (2010, 2011); Cappo et al

(2011); Göetze et al .(2011);

Lowry et al. (2011) ;Martinez et

al. (2011) ; Birt et al. (2012)

Fitzpatrick et al. (2012) ;

Gladstone et al. (2012) ; Harvey

et al. $(2012 a, b)$; Schultz et al.

$$
\text { (2012) }
$$

(25 references)
Alevizon and Brooks (1975); Davis and Anderson (1989); Greene and Alevizon (1989); Aronson et al. (1994); Bortone et al. (1991, 1994); Parker et al. (1994); Ninio et al. (2000); Tessier et al. (2005) ; Watson et al. (2005, 2010); Langlois et al. (2010); Pelletier et al.

$$
\text { (2011) }
$$

\section{(13 references)}

Handley et al. (2003); Dunbrack (2006) NR $\quad \begin{gathered}\text { Holme and Barrett (1977); } \\ \text { Spencer et al. (2005) }\end{gathered}$

Machan and Fedra (1975); Holme and Barrett (1977); Norris et al. (1997); Riegl et al. (2001); Rosenkranz and Byersdorfer (2004); Spencer et al. (2005); Hayashizaki and Ogawa (2006); McDonald et al. (2006); Bucas et

$$
\text { al. (2007); Rooper and }
$$

Zimmermann (2007); Smith et al. (2007); Grizzle et al. (2008); Carbines and Cole (2009); Bulh-

Mortensen et al. (2012);

Grabowski et al. (2012) (15 references)
Leonard and Clark (1993); Aronson et al. (1994);

Carleton and Done (1995);

Vogt et al. (1997); Ninio et al. (2000); Rogers and Miller (2001); Watson et al. (2005, 2010); Houk and Van Woesik (2006); Kenyon et al. (2006); Lam et al. (2006); Leujak and Ormond (2007); Cruz et al. (2008); Tilot et al.

(2008); Langlois et al. (2010)

(15 references) 
Table 6. Metrics computed from the main video techniques. The list of metrics may depend on the particular implementation of the technique.

Frequency of occurrence, presence/absence per species

Species richness

Abundance or abundance density per species

RUV Or per size class of the species : maximum and DOV abundance seen during the observation period, or mean abundance over viewing intervals during the observation period Number of bites by herbivores Distance from fish to the camcorder Occurrences of activities per individual
Percent cover of abiotic substrate Habitat topography and complexity Percent cover of epifauna and epiflora

Number of species within the field of view during the observation period Maximum fish abundance seen during the

BRUV observation period

Maximum number of individuals per species

simultaneously observed during the observation (MaxN)

Time to first appearance per species

TOWV

Abundance and percent cover of some macroinvertebrate species

Abundance of epibenthic species Percent cover of epifauna and epiflora

Percent cover of biotic and abiotic substrate and habitat Habitat topography and complexity 
Table 7. Studies comparing techniques. NR indicates that No reference was found in the literature search.

Only studies with a protocol aimed at comparing data from distinct techniques were quoted.

\begin{tabular}{|c|c|c|c|c|c|c|}
\hline & RUV & $\begin{array}{l}\text { Stereo } \\
\text { RUV }\end{array}$ & BRUV & $\begin{array}{l}\text { Stereo } \\
\text { BRUV }\end{array}$ & TOWV & DOV \\
\hline RUV & NR & $\begin{array}{l}\text { Harvey et al. } \\
(2002 b)\end{array}$ & $\begin{array}{c}\text { Harvey et al. (2007); } \\
\text { Bernard and Götz } \\
(2012)\end{array}$ & NR & NR & NR \\
\hline $\begin{array}{l}\text { Stereo } \\
\text { BRUV }\end{array}$ & NR & $\begin{array}{l}\text { Watson et al. } \\
(2005)\end{array}$ & NR & NR & NR & NR \\
\hline TOWV & NR & NR & $\begin{array}{c}\text { Morrison and } \\
\text { Carbines (2006); } \\
\text { Monk et al. (2012) }\end{array}$ & NR & & NR \\
\hline $\begin{array}{l}\text { Stereo } \\
\text { DOV }\end{array}$ & NR & $\begin{array}{l}\text { Watson et al. } \\
(2005)\end{array}$ & NR & $\begin{array}{c}\text { Langlois et al. } \\
(2010) ; \\
\text { Watson et al. } \\
(2010)\end{array}$ & NR & NR \\
\hline UVC & $\begin{array}{l}\text { Francour et } \\
\text { al. (1999); } \\
\text { Cooke and } \\
\text { Schreer } \\
\text { (2002); } \\
\text { Fox and } \\
\text { Bellwood } \\
\text { (2008); } \\
\text { Burge et al. } \\
\text { (2012); } \\
\text { Longo and } \\
\text { Floeter } \\
\text { (2012); } \\
\text { McCauley et } \\
\text { al. (2012) }\end{array}$ & $\begin{array}{l}\text { Harvey et al. } \\
\text { (2001a,b, } \\
2002 a, \\
2004) ; \\
\text { Cappo et al. } \\
\text { (2003) }\end{array}$ & $\begin{array}{l}\text { Willis and Babcock } \\
\text { (2000); Willis et al. } \\
\text { (2000); Westera et al. } \\
\text { (2003); Langlois et al. } \\
\text { (2006); Morrison and } \\
\text { Carbines (2006); } \\
\text { Stobart et al. (2007); } \\
\text { Colton and Swearer } \\
\text { (2010); Burge et al. } \\
\text { (2012); Lowry et al. } \\
\text { (2012) }\end{array}$ & NR & $\begin{array}{l}\text { Morrison } \\
\text { and } \\
\text { Carbines } \\
(2006) ; \\
\text { Assis et al. } \\
\text { (2007); } \\
\text { Leujak and } \\
\text { Ormond } \\
\text { (2007) }\end{array}$ & $\begin{array}{l}\text { Greene and } \\
\text { Alevizon } \\
\text { (1989); } \\
\text { Michalopoulos } \\
\text { et al. (1992); } \\
\text { Leonard and } \\
\text { Clarck (1993); } \\
\text { Rogers and } \\
\text { Miller (2001); } \\
\text { Tessier et al. } \\
\text { (2005); Lam et } \\
\text { al. (2006); } \\
\text { Pelletier et al. } \\
\text { (2011) }\end{array}$ \\
\hline Fishing & $\begin{array}{l}\text { Cooke and } \\
\text { Schreer } \\
\text { (2002); Wells } \\
\text { et al. (2008) }\end{array}$ & NR & $\begin{array}{l}\text { Ellis and DeMartini } \\
\text { (1995); Willis et al. } \\
\text { (2000); Cappo et al. } \\
\text { (2004); Morrison and } \\
\text { Carbines (2006); } \\
\text { Bloomfield et al. } \\
\text { (2012) }\end{array}$ & $\begin{array}{l}\text { Harvey et al. } \\
(2012 \mathrm{c}) ; \\
\text { Langlois et al. } \\
(2012 \mathrm{a})\end{array}$ & $\begin{array}{l}\text { Morrison } \\
\text { and } \\
\text { Carbines } \\
(2006)\end{array}$ & NR \\
\hline Acoustic & NR & NR & Gledhill et al. (1996) & NR & NR & NR \\
\hline
\end{tabular}


Table 8. Main outcomes of comparative studies involving video techniques (see references and

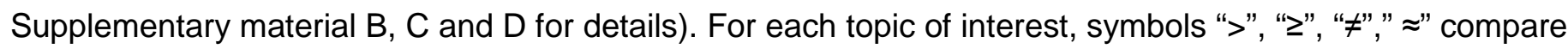
the number of items or the assemblage structure detected by the two techniques, which may represent a qualitative summary over several results.

\begin{tabular}{|c|c|}
\hline \multicolumn{2}{|r|}{ FISH } \\
\hline & pecies richness \\
\hline $\begin{array}{l}\text { UVC }>\text { H-BRUV }>\text { V-BRUV } \\
\text { UVC }>\text { BRUV }\end{array}$ & $\begin{array}{l}\text { Langlois et al. (2006) } \\
\text { Colton and Swearer (2010) }\end{array}$ \\
\hline UVC $>$ RUV & Francour et al. (1999) \\
\hline RUV $>$ UVC \& Experimental fishing & Cooke and Schreer (2002) \\
\hline $\begin{array}{l}\text { UVC } \geq \text { DOV } \\
\text { UVC }>\text { DOV }\end{array}$ & $\begin{array}{l}\text { Pelletier et al. (2011) } \\
\text { Green and Alevizon (1989) }\end{array}$ \\
\hline TOWV > UVC & Assis et al. (2007) \\
\hline BRUV > RUV \& DOV & Watson et al. (2005) ; Bernard and Götz (2012) \\
\hline$R U V>$ BRUV & Harvey et al. (2007) \\
\hline BRUV > DOV & Langlois et al. (2010); Watson et al. (2010) \\
\hline BRUV > Exp. Fishing / Traps & Ellis and DeMartini (1995); Harvey et al. (2012b) \\
\hline \multicolumn{2}{|r|}{ Assemblage structure } \\
\hline UVC $\neq$ BRUV & Colton and Swearer (2010) \\
\hline $\mathrm{BRUV} \approx \mathrm{UVC}$ & Westera et al. (2003) \\
\hline$B R U V \neq R U V \neq D O V$ & Watson et al. 2005) \\
\hline BRUV $\neq$ DOV & Langlois et al. (2010); Watson et al. (2010) \\
\hline BRUV $\neq$ TRAWL & Cappo et al. (2004) \\
\hline BRUV > Traps & Harvey et al. (2012b) \\
\hline & Abundance \\
\hline UVC > BRUV & Langlois et al. (2006); Colton and Swearer (2010) \\
\hline UVC $\geq \mathrm{DOV}$ & Pelletier et al. (2011) \\
\hline TOWV > UVC & Assis et al. (2007) \\
\hline RUV > UVC \& Exp. Fishing & Cooke and Schreer (2002) \\
\hline$B R U V>R U V$ & Harvey et al. (2007) ; Bernard and Götz (2012) \\
\hline BRUV $\neq$ DOV (depends on family) & Watson et al. (2010) \\
\hline UVC $\neq$ DOV (depends on family) & Pelletier et al. (2011) \\
\hline BRUV > Traps & Harvey et al. (2012b) \\
\hline \multicolumn{2}{|r|}{ Occurrences } \\
\hline BRUV > Experimental fishing & Ellis and DeMartini (1995); Harvey et al. (2012b) \\
\hline \multicolumn{2}{|c|}{ HABITAT - BENTHOS } \\
\hline $\begin{array}{l}\text { UVC > DOV: Diversity of coralline algae } \\
\text { observed }\end{array}$ & Leonard and Clark (1993) \\
\hline DOV $\approx$ UVC: Live coral cover & Rogers and Miller (2001) \\
\hline $\begin{array}{l}\text { DOV > UVC: } \\
\text { \% Coral cover } \\
\text { Occurrence of Gorgonians \& } \\
\text { Macroalgae, \% Bleached coral }\end{array}$ & $\begin{array}{l}\text { Lam et al. (2006) } \\
\text { Rogers and Miller (2001) }\end{array}$ \\
\hline TOWV > UVC: \% Benthic cover & Leujak and Ormond (2007) \\
\hline
\end{tabular}


Table 9. Cost-related information per technique.

\begin{tabular}{|c|c|c|}
\hline & Reference & Staff time per station (hrs) \\
\hline \multirow{2}{*}{ RUV } & Bernard and Götz (2012) & 3.5 \\
\hline & Pelletier et al. (2012) (ROT-RUV) & $0.5-1.6$ \\
\hline \multirow{3}{*}{ BRUV } & Langlois et al. (2010) (stereo-BRUV) & $1.75-3$ \\
\hline & Bernard and Götz (2012) & 7.0 \\
\hline & Gladstone et al. (2012) & 1.5 (soaktime only) \\
\hline \multirow{3}{*}{ DOV } & Leujak and Ormond (2007) & \\
\hline & Langlois et al. (2010) (stereo-DOV) & $0.75-1.8$ \\
\hline & Pelletier et al. (2011) & $0.4-2.5$ \\
\hline TOWV & See Table 3 & depends on tow length \\
\hline \multirow{3}{*}{ UVC } & Pelletier et al. (2011) (strip transect) & $0.75-1.5$ \\
\hline & Bohnsack and Bannerot (1986) (stationary point count) & \\
\hline & Leujak and Ormond (2007) (Line Intercept Transect) & 1.25 \\
\hline
\end{tabular}


Table 10. Comparison of the main advantages and shortcomings of each observation technique and recommendations for future use. UVC, fishing and acoustics are reported for comparison.

\begin{tabular}{|c|c|c|c|}
\hline Methods & Advantages & Shortcomings & Recommendations \\
\hline RUV & $\begin{array}{c}\text { Non extractive } \\
\text { Least invasive method } \\
\text { Constant observation duration } \\
\text { Does not require diver } \\
\text { Possible observation at large depth } \\
\text { Fast implementation } \\
\text { Possible participation of non- } \\
\text { scientific staff }\end{array}$ & $\begin{array}{l}\text { Duration of image } \\
\text { analysis } \\
\text { Management of large } \\
\text { data sets }\end{array}$ & $\begin{array}{l}\text { Diurnal and seasonal } \\
\text { patterns of behaviour, } \\
\text { species activity and } \\
\text { abundance over long } \\
\text { periods/at high frequencies } \\
\text { Highly spatially-replicated } \\
\text { designs } \\
\text { Monitoring of conspicuous } \\
\text { and target species }\end{array}$ \\
\hline BRUV & $\begin{array}{c}\text { Non extractive } \\
\text { Increased observed fish abundance } \\
\text { through baiting } \\
\text { Constant observation duration } \\
\text { Does not require diver } \\
\text { Opportunity to work in deep water } \\
\text { Possible participation of non- } \\
\text { scientific staff }\end{array}$ & $\begin{array}{c}\text { Unknown effect of bait } \\
\text { plume } \\
\text { Relatively long } \\
\text { observation duration } \\
\text { Duration of image } \\
\text { analysis } \\
\text { Management of large } \\
\text { data sets }\end{array}$ & $\begin{array}{l}\text { Monitoring populations of } \\
\text { fishes, and particularly } \\
\text { carnivorous species } \\
\text { Monitoring in areas where } \\
\text { diversity and abundance are } \\
\text { low }\end{array}$ \\
\hline TOWV & $\begin{array}{c}\text { Non extractive } \\
\text { Does not require diver } \\
\text { Opportunity to work in deep water } \\
\text { Fast implementation } \\
\text { Large spatial coverage } \\
\text { Possible participation of non- } \\
\text { scientific staff }\end{array}$ & $\begin{array}{l}\text { May disturb the } \\
\text { ecosystem due to } \\
\text { vessel noise } \\
\text { Management of large } \\
\text { data sets } \\
\text { Duration of image } \\
\text { analysis }\end{array}$ & $\begin{array}{c}\text { Monitoring habitat and fixed } \\
\text { benthic species over large } \\
\text { areas }\end{array}$ \\
\hline DOV & $\begin{array}{c}\text { Non extractive } \\
\text { Does not require scientific diver }\end{array}$ & $\begin{array}{c}\text { All effects associated } \\
\text { with the presence of } \\
\text { a diver underwater } \\
\text { (see below) } \\
\text { Duration of image } \\
\text { analysis }\end{array}$ & $\begin{array}{l}\text { Study benthic cover and } \\
\text { macrofauna }\end{array}$ \\
\hline UVC & $\begin{array}{c}\text { Non extractive } \\
\text { Widely used } \\
\text { Possible participation of volunteers } \\
\text { for simplified protocols }\end{array}$ & $\begin{array}{c}\text { Observer effect } \\
\text { Diver effect } \\
\text { Depth limitation } \\
\text { Requires diver trained } \\
\text { to species } \\
\text { identification and } \\
\text { counting } \\
\text { Observation duration }\end{array}$ & $\begin{array}{c}\text { Studies at species level } \\
\text { Inventories and species } \\
\text { counts } \\
\text { Small species }\end{array}$ \\
\hline Fishing & $\begin{array}{c}\text { Extractive } \\
\text { Does not require diver } \\
\text { Possible observation at large depth } \\
\text { Possible participation of fishers }\end{array}$ & $\begin{array}{c}\text { Unknown observation } \\
\text { volume and species } \\
\text { catchability }\end{array}$ & Monitoring of resources \\
\hline Acoustics & $\begin{array}{c}\text { Non extractive } \\
\text { Spatial coverage } \\
\text { Possible observation at large depth }\end{array}$ & $\begin{array}{c}\text { High-tech analysis of } \\
\text { data } \\
\text { No species } \\
\text { identification }\end{array}$ & $\begin{array}{c}\text { Monitoring of resources } \\
\text { coupled with another } \\
\text { technique, e.g. fishing } \\
\text { More suitable for pelagic } \\
\text { species }\end{array}$ \\
\hline
\end{tabular}




\section{Figures}

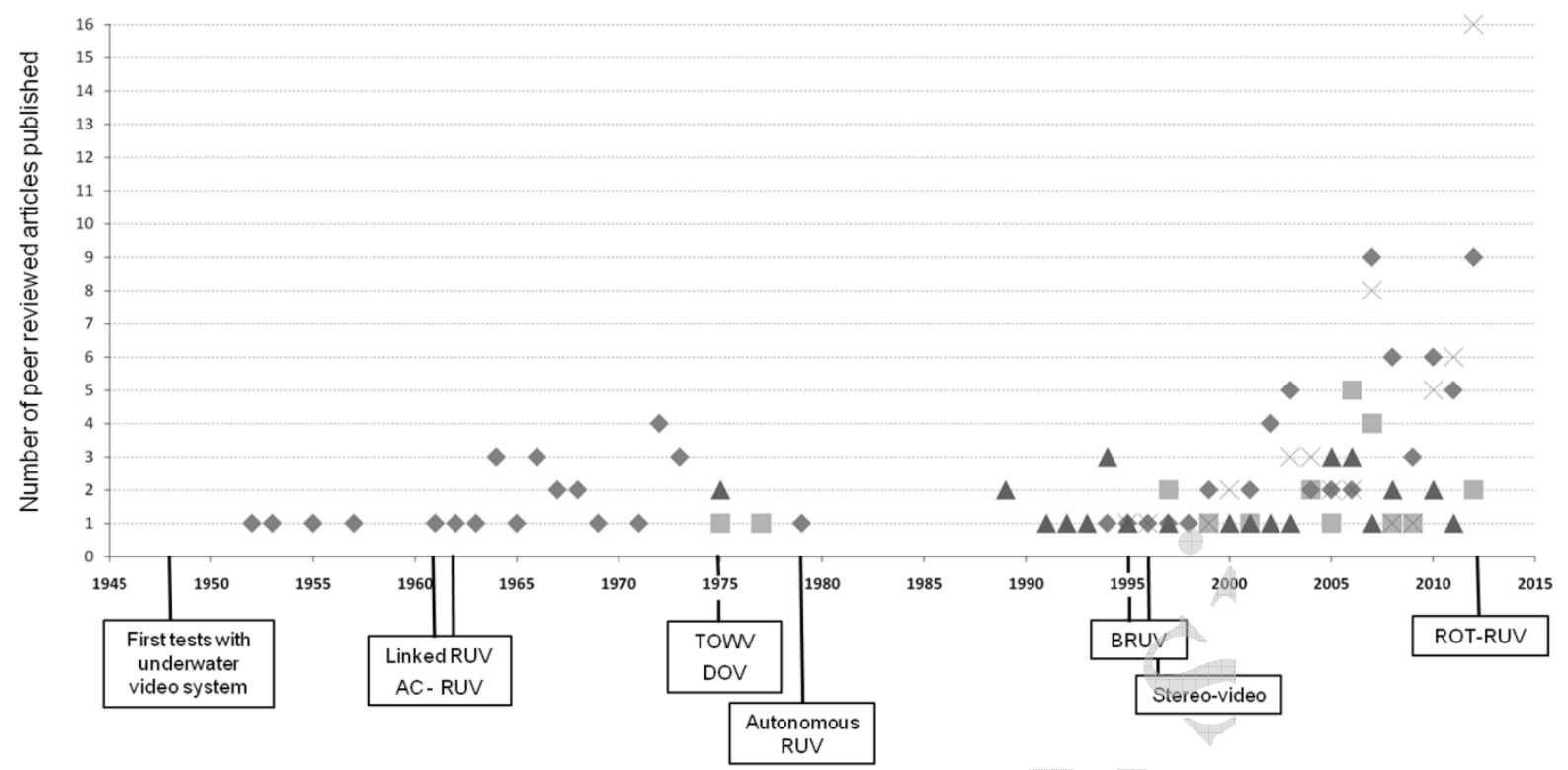

Figure 1. Historical perspective on the development of underwater video systems, with associated papers ( RUV; $\square$ TOWV; $\triangle$ DOV; X BRUV).

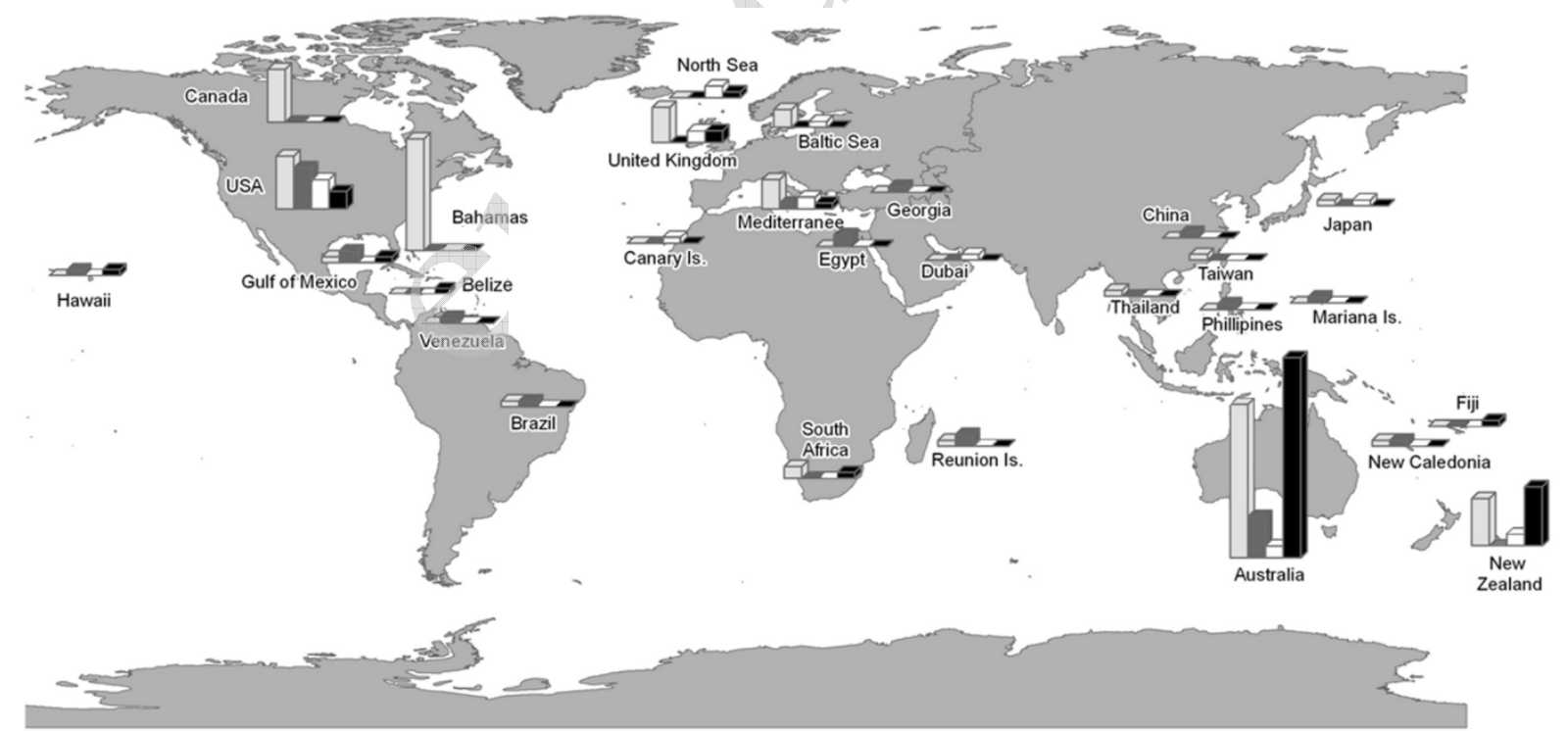

Figure 2. Geographical distribution of published studies. Each bar is proportional to the number of papers published for each technique: $\square$ RUV; $\quad$ DOV; $\square$ TOWV and BRUV. The number of papers published by year and country per technique are given in Supplementary Material A. 
Supplementary material A. Geographical distribution of reviewed studies. Numbers after each region correspond to references available at the end of this document. They are classified from the oldest to the most recent reference for each region.

Technique Region

United Kingdom 9, 10, 11, 31,7

USA $6,108,23,136,59,8,30,78,126$

USA

$98,159,107,147,138,41,42,134,135,43,154$

Mediterranean sea $62,46,52,146,1,45$

Canada ${ }^{103,145,58,56,61,57}$

New Zealand ${ }^{79}, 80,68,81,82,83,84,77$,

$\mathrm{New}_{85,87}$

Australia $16,35,89,171,17,65,122,123,172$, $15,66,67,130,49,94,93,95,167,18,96,114,168$

RUV

Ireland ${ }^{101,72}$

Baltic sea ${ }^{63}$

Taiwan

Gulf of Mexico ${ }^{175}$

Thailand ${ }^{51}$

South Africa ${ }^{14,19}$

Brazil ${ }^{117}$

Japan ${ }^{125}$

New Caledonia ${ }^{144}$

Reunion Is. ${ }^{39}$

Published years

1952 - 2002

$1957-2012$

$1962-1973$

$1979-2012$

$1994-2008$

$1995-2007$

$2003-2012$

$2004-2009$

2007

2007

2008

2010

$2010-2012$

2012

2012

2012

2012

Mediterranean sea ${ }^{120,15}$

United Kingdom 97, 153

Philippines ${ }^{69}$

USA $141,151,162,156,150,75$

New Zealand 26, 133, 37

Dubai ${ }^{148}$

TOWV

Australia ${ }^{127,132}$

Hawaï ${ }^{102}$

Japan

Baltic sea ${ }^{27}$

Canary Is.

Iceland 73

Norway ${ }^{28}$

$1975-2007$

1977 - 2006

1997

$1997-2008$

1999 - 2009

2001

$2006-2012$

2006

2006

2007

2007

2012

2012
Technique

Region

Published years

Venezuela

USA 2, 50, 74, 131, 115, 3, 149

Gulf of Mexico ${ }^{24,25}$

Georgia ${ }^{142}$

Australia 38, 139, 76, 140, 171, 112, 174

Philippines 169

1997

China ${ }^{109}$

Hawaï ${ }^{102}$

Mariana Is. ${ }^{99}$

Egypt ${ }^{116}$

Brazil

New Caledonia ${ }^{143}$

1975

1975 - 2001

1991 - 1994

1994

$995-2010$

1997
2005

2006

2006

2006

2007 - 2008

2008

2011
Hawaï ${ }^{60}$

Gulf of Mexico ${ }^{70}$

New Zealand 5, 177, 179, 180, 53, 54, 178, 111

$133,87,13$ $181,173,112,174,40,44,129,36,118,128,20,55$ $64,69,86,88,90,110,113,119,132,152,182$

Mediterranean sea ${ }^{161}$

USA 163,29

Fiji $^{7}$

North sea ${ }^{124}$

Belize 22

United Kingdom ${ }^{21}$
Australia $35,176,32,171,33,34,92,121,170$,
1995

$1999-2011$

$2003-2012$

2007

$2008-2012$

2011

2011

2012

2012 
Supplementary material B. Main outcomes of the studies comparing a video technique with UVC (62\% of comparative studies, Table 7). H-BRUV=Horizontal Remote Underwater Video, RUV=Remote Underwater Video, SRUV=stereo remote underwater video, DOV= Diver-Operated Video, TOWV = towed video, UVC=underwater visual census, V-BRUV=Vertical Remote Underwater Video.

\section{Main outcomes}

Highlight known taxa-specific attraction or repulsion effects with respect to diver ${ }^{68}$.

Divers could make observations that were not possible from RUV (underwater perception \& mobility) ${ }^{68}$.

RUV Density estimates of the five most abundant fish species were always greater from UVC than from

UVC RUV68.

RUV permitted the detection of the most species and the largest number of individuals ${ }^{46}$.

RUV was more cost-effective than UVC ${ }^{68}$.

Variable visibility was the main limitation of the video technique ${ }^{46}$.

Highlight diver effect (difference in estimates made by beginners vs. experienced scientific divers) ${ }^{81,82,83}$. Low variability around true lengths estimates made by SRUV ${ }^{81,83}$.

The coefficient of variation of fish length estimate was significantly lower for SRUV than for UVC ${ }^{81,82}$.

SRUV The power to detect changes in mean length was higher with SRUV ${ }^{81,82}$.

UVC $\quad \mathrm{cm})^{83}$ and precision depended on the distance ${ }^{84}$.

The error in the estimates increased as the individual moved away from the diver ${ }^{84}$.

Diver-based estimates were less accurate than the stereo-video technique ${ }^{83}$.

Distance was underestimated by divers ${ }^{84}$.

BRUV recorded a larger number of species ${ }^{110,172,176}$, more mobile predators ${ }^{48}$ and a larger abundance of Lethrinidae ${ }^{175}$ than UVC

BRUV UVC recorded larger species richness and abundance (in terms of all species, herbivores, cryptic

UVC Species, and most territorial species), higher richness, and higher biodiversity ${ }^{44,}$.

BRUV was not suitable for the estimation of small snapper densities in an area of very high juvenile densities $^{133}$.

Density and average size was significantly larger for V-BRUV than for UVC ${ }^{176,178 .}$

UVC recorded a larger abundance and diversity of fish ${ }^{110}$.

V-BRUV Relative fish density was similar for both methods ${ }^{178}$.

UVC V-BRUV was an effective (and sometimes superior) alternative to UVC methods for estimating relative densities of predatory reef fish ${ }^{176}$.

Lethrinidae and Serranidae did not approach the video system when the camera was above them ${ }^{110}$.

Species richness, abundance, overall sampling effort and total surveyed area (121.968 ha vs. 0.310 ha)

TOWV were higher when using TOWV4.

UVC TOWV estimates provided the most accurate coverage of major categories of benthic substrate ${ }^{116}$. TOWV only partially detected the very small fish but was more appropriate for larger individuals ${ }^{133}$. TOWV was more effective in term of observed size range, abundance estimates and cost ${ }^{133}$.

UVC recorded more red algae taxa than DOV, and DOV tended to overestimate the percent cover of rock and articulated coralline algae ${ }^{115}$

DOV detected more individuals but UVC identified more species ${ }^{74}$.

UVC was more accurate, better detected trends over time ${ }^{109}$, recorded larger abundance and species richness $^{143}$, and was more cost-effective ${ }^{115}$.

DOV provided representative observations of fish abundance and species diversity, although fewer species and individuals were detected ${ }^{143}$.

DOV Coral cover estimates were similar, but DOV-based cover estimates were higher for coral bleaching,

UVC gorgonians and macroalgae ${ }^{149}$.

UVC overestimated the percent coral cover in coral-rich areas ${ }^{109}$.

DOV and UVC yielded similar values for coral cover ${ }^{149}$.

Browsing DOV detected more individuals and species than straight DOV, conducting DOV before or after UVC did not affect DOV observations ${ }^{143}$.

The proportion of fish that were not identified up to the species level was $3.3 \%$ in High Definition video observations vs $1.7 \%$ in UVC ${ }^{143}$. 
Supplementary material C. Main outcomes of comparisons between video techniques (19\% of all comparative studies, Table 7)

Techniques

Main outcomes

stereo-RUV Estimates were significantly more accurate and precise with the stereo-RUV than with the RUV monovideo ${ }^{84}$.

stereo-RUV

Species richness based on stereo-RUV was larger in diversified habitat and lesser in lower reef stereo-BRUV relief, while species richness based on stereo-BRUV was similar in the 2 habitats, and the relative abundance of rare and large predators and species richness were larger ${ }^{172}$. None of the techniques sampled small cryptic species (s.a. Gobiidae and Blenniidae) ${ }^{172}$.

Stereo-DOV recorded more species (42 vs. 23) and sampled more smaller or cryptic species than other methods (divers looked for them) ${ }^{172}$.

Stereo-RUV Labridae richness was higher from stereo-RUV ${ }^{172}$

Stereo-DOV Both techniques detected a larger number of species in diversified habitat and a lesser number in lower reef relief ${ }^{172}$.

None of the techniques identified small cryptic species (s.a. Gobiidae and Blenniidae) ${ }^{172}$.

RUV regions) $)^{87}$.

BRUV recorded difference in fish assemblages between habitats (in both temperate and tropical

BRUV The bait attracted a larger number of carnivores and scavengers without decreasing the representativeness of other trophic groups such as herbivores or omnivores ${ }^{87}$.

H-BRUV H-BRUV detected more fish individuals than V-BRUV ${ }^{111}$. (which was found to work well in New

V-BRUV Zealand ${ }^{176,178}$ )

H-BRUV recorded 14 species versus 3 species from V-BRUV ${ }^{111}$.

DOV detected a larger number of species in diversified habitat and lesser in lower reef relief ${ }^{172}$. DOV detected a larger abundance of small Pomacentridae, Labridae and Scaridae ${ }^{171}$.

Species richness based on stereo-BRUV was similar in the 2 habitats, and the relative abundance of rare and large predators and species richness were larger ${ }^{172}$.

Stereo-BRUV observed larger species richness, larger relative biomasses of generalist

stereo-BRUV carnivores. Spatial and temporal changes in fish assemblage were better detected from stereo-

DOV BRUV ${ }^{110}$.

Stereo-BRUV was cost-effective for monitoring fish assemblages ${ }^{110}$.

Observed species richness was $40 \%$ higher with stereo-BRUV compared to DOV. The number

and abundance of large target species were larger, as well as many non target species ${ }^{171}$.

None of the techniques detected small cryptic species (s.a. Gobiidae and Blenniidae) ${ }^{172}$.

No difference in the biomass of herbivores observed by the 2 techniques ${ }^{110}$.

Data from BRUV could not be converted into density estimates per unit area ${ }^{133}$.

BRUV were not suitable for the estimation of small snapper densities in an area of very high

V-BRUV juvenile densities ${ }^{133}$.

TOWV TOWV only partially detected the very small fish but was more appropriate for larger individuals ${ }^{133}$.

TOWV was more effective in term of observed size range, abundance estimates and cost ${ }^{133}$. 
Supplementary material D. Main outcomes of comparisons between a video technique and fishing or acoustics (14\% of all comparative studies about fishing techniques and $5 \%$ about acoustics, Table 7 )

\section{Techniques \\ Main outcomes}

RUV RUV detected more species and individuals ${ }^{46}$.

Fishing Variable visibility was the main limitation of the video technique ${ }^{46}$.

BRUV recorded more species and individuals than fishing ${ }^{46}$

BRUV Trawling recorded mostly sedentary, cryptic and demersal species, but also more nocturnal

Fishing species $^{32}$. BRUV recorded larger and more mobile species ${ }^{32}$.

Observed size structures were consistent between the two techniques ${ }^{178}$.

Relative densities were similar for both techniques ${ }^{178}$.

V-BRUV Fishing recorded the largest species number ${ }^{133}$.

Fishing Data from V-BRUV could not be converted into density estimates per unit area ${ }^{133}$.

V-BRUV was not suitable for the estimation of small snapper densities in an area of very high juvenile densities $^{133}$.

Fishing recorded the largest species number ${ }^{133}$

TOWV only partially detected the very small fish but was more appropriate for larger

Fishing individuals ${ }^{133}$.

TOWV was more effective in term of observed size range, abundance estimates and $\operatorname{cost}^{133}$.

BRUV abundance ${ }^{70}$.

Acoustic Video data provided species identifications and abundance estimates that may vary with water clarity $^{70}$.

Acoustic data were not dependent on visibility ${ }^{70}$. 


\section{References cited in supplementary materials}

1. Aguzzi, J., Manuel, A., Condal, F., Guillen, J., Nogueras, M., del Rio, J., Costa, C., Menesatti, P., Puig, P., Sarda, F., Toma, D., Palanques, A., 2011. The New Seafloor Observatory (OBSEA) for Remote and Long-Term Coastal Ecosystem Monitoring. Sensors 11, 5850-5872.

2. Alevizon, W.S., Brooks, M.G., 1975. The comparative structure of two Western Atlantic reef-fish assemblages. Bulletin of Marine Science 25, 482-490.

3. Aronson, R.B., Edmunds, P.J., Precht, W.F., Swanson, D.W., Levitan, D.R., 1994. Large-scale, longterm monitoring of Caribbean coral reefs: simple, quick, inexpensive techniques. Atoll Research Bulletin 421, 1-19.

4. Assis, J., Narváez, K., Haroun, R., 2007. Underwater towed video: a useful tool to rapidly assess elasmobranch populations in large marine protected areas. Journal of Coastal Conservation 11, 153157.

5. Babcock, R.C., Kelly, S., Shears, N.T., Walker, J.W., Willis, T.J., 1999. Changes in community structure in temperate marine reserves. Marine Ecology Progress Series 189, 125-134.

6. Backus, R.H., Barnes, H., 1957. Television-echo sounder observations of midwater sound scatterers. Deep-Sea Research 4, 116-119.

7. Barans, C.A., Arendt, M.D., Moore, T., Schmidt, D., 2005. Remote video revisited: A visual technique for conducting long-term monitoring of reef fishes on the continental shelf. Marine Technology Society Journal 39, 110-118.

8. Barans, C.A., Schmidt, D., Brouwer, M.C., 2002. Potential for coupling of underwater TV monitoring with passive acoustics, in: Rountree, R., Goudey, C., Hawkins, T., Luczkovich, J.J., Mann, D. (Eds.), Listening to Fish: Proceedings of the International Workshop on the Applications of Passive Acoustics to Fisheries. Massachusetts Institute of Technology Cambridge, USA, p. 172.

9. Barnes, H., 1952. Under-water television and marine biology. Nature 169, 477-479.

10. Barnes, H., 1953. Underwater television and research in marine biology, bottom topography and geology. I. A description of the equipment and its use on board ship. Deutsche Hydrographische Zeitschrift 6, 123-133.

11. Barnes, H., 1955. Underwater television and research in marine biology, bottom topography and geology. II. Experience with the equipment. Deutsche Hydrographische Zeitschrift 8, 213-236.

12. Barnes, H.B., 1963. Underwater television. Oceanography and Marine Biology: An Annual Review 11, 115-128.

13. Bassett, D.K., Montgomery, J.C., 2011. Investigating nocturnal fish populations in situ using baited underwater video: With special reference to their olfactory capabilities. Journal of Experimental Marine Biology and Ecology 409, 194-199.

14. Becker, A., Cowley, P.D., Whitfield, A.K., 2010. Use of remote underwater video to record littoral habitat use by fish within a temporarily closed South African estuary. Journal of Experimental Marine Biology and Ecology 391, $161-168$.

15. Bellwood, D.R., Fulton, C.J., 2008. Sediment-mediated suppression of herbivory on coral reefs: decreasing resilience to rising sea levels and climate change? Limnology and Oceanography 53, 26952701.

16. Bellwood, D.R., Hoey, A.S., Choat, J.H., 2003. Limited functional redundancy in high diversity systems: resilience and ecosystem function on coral reefs. Ecology Letters 6, 281-285.

17. Bellwood, D.R., Hughes, T.P., Hoey, A.S., 2006. Sleeping functional group drives coral-reef recovery. Current Biology 16, 2434-2439.

18. Bennett, S., Bellwood, D.R., 2011. Latitudinal variation in macroalgal consumption by fishes on the Great Barrier Reef. Marine Ecology Progress Series 426, 241-U269.

19. Bernard, A.T.F., Götz, A., 2012. Bait increases the precision in count data from remote underwater video for most subtidal reef fish in the warm-temperate Agulhas bioregion. Marine Ecology Progress Series 471, 235-252. 
20. Birt, M.J., Harvey, E.S., Langlois, T.J., 2012. Within and between day variability in temperate reef fish assemblages: Learned response to baited video. Journal of Experimental Marine Biology and Ecology 416-417, 92-100.

21. Bloomfield, H.J., Sweeting, C.J., Mill, A.C., Stead, S.M., Polunin, N.V.C., 2012. No-trawl area impacts: perceptions, compliance and fish abundances. Environmental Conservation 39, 237-247.

22. Bond, M.E., Babcock, E.A., Pikitch, E.K., Abercrombie, D.L., Lamb, N.F., Chapman, D.D., 2012. Reef Sharks Exhibit Site-Fidelity and Higher Relative Abundance in Marine Reserves on the Mesoamerican Barrier Reef. PLoS ONE 7.

23. Booda, L.L., 1966. Industry bees swarm at NEL. UnderSea Technology 7, 23-25.

24. Bortone, S.A., Martin, T., Bundrick, C.M., 1991. Visual census of reef fish assemblages: A comparison of slate, audio, and video recording devices. Northeast Gulf Science 12, 17-23.

25. Bortone, S.A., Martin, T., Bundrick, C.M., 1994. Factors Affecting Fish Assemblage Development on a Modular Artificial Reef in a Northern Gulf of Mexico Estuary. Bulletin of Marine Science 55, 319-332.

26. Bräger, S., Chong, A., Dawson, S., Slooten, E., Würsig, B., 1999. A combined stereo-photogrammetry and underwater-video system to study group composition of dolphins. Helgoland Marine Research 53, 122-128.

27. Bucas, M., Daunys, D., Olenin, S., 2007. Overgrowth patterns of the red algae Furcellaria lumbricalis at an exposed Baltic Sea coast: The results of a remote underwater video data analysis. Estuarine, Coastal and Shelf Science 75, 308-316.

28. Buhl-Mortensen, L., Buhl-Mortensen, P., Dolan, M.F.J., Dannheim, J., Bellec, V., Holte, B., 2012. Habitat complexity and bottom fauna composition at different scales on the continental shelf and slope of northern Norway. Hydrobiologia 685, 191-219.

29. Burge, E.J., Atack, J.D., Andrews, C., Binder, B.M., Hart, Z.D., Wood, A.C., Bohrer, L.E., Jagannathan, K., 2012. Underwater Video Monitoring of Groupers and the Associated Hard-Bottom Reef Fish Assemblage of North Carolina Bulletin of Marine Science 88, 15-38.

30. Burkepile, D.E., Hay, M.E., 2011. Feeding complementarity versus redundancy among herbivorous fishes on a Caribbean reef. Coral Reefs 30, 251-362.

31. Burrows, M.T., Kawai, K., Hughes, R.N., 1999. Foraging by mobile predators on a rocky shore: underwater TV observations of movements of blennies Lipophrys pholis and crabs Carcinus maenas. Marine Ecology Progress Series 187, 237-250.

32. Cappo, M., De'ath, G., Speare, P., 2007. Inter-reef vertebrate communities of the Great Barrier Reef Marine Park determined by baited remote underwater video stations. Marine Ecology Progress Series 350, 209-221.

33. Cappo, M., Harvey, E., Malcolm, H., Speare, P., 2003. Potential of video techniques to monitor diversity, abundance and size of fish in studies of marine protected areas, in: Beumer, J.P., Grant, A., Smith, D.C. (Eds.), APAC Congress 2002: Aquatic protected areas - What works best and how do we know ? World Congress on Aquatic Protected Areas proceedings. National Library of Australia, Cairns, Qld, Australia, pp. 455 - 464.

34. Cappo, M., Harvey, E., Shortis, M., 2007. Counting and measuring fish with baited video techniques an overview, in: Lyle, J.M., Furlani, D.M., Buxton, C.D. (Eds.), Proceedings of the 2006 Australian Society of Fish Biology Conference and Workshop Cuttingedge Technologies in Fish and Fisheries Science, Hobart, August 2006, pp. 101-114.

35. Cappo, M., Speare, P., De'ath, G., 2004. Comparison of baited remote underwater video stations (BRUVS) and prawn (shrimp) trawls for assessments of fish biodiversity in inter-reefal areas of the Great Barrier Reef Marine Park. Journal of Experimental Marine Biology and Ecology 302 123-152.

36. Cappo, M., Stowar, M., Syms, C., Johansson, C., Cooper, T., 2011. Fish-habitat associations in the region offshore from James Price Point - a rapid assessment using Baited Remote Underwater Video Stations (BRUVS). Journal of the Royal Society of Western Australia 94, 303-321.

37. Carbines, G., Cole, R.G., 2009. Using a remote drift underwater video (DUV) to examine dredge impacts on demersal fishes and benthic habitat complexity in Foveaux Strait, Southern New Zealand. Fisheries Research 96 230-237. 
38. Carleton, J.H., Done, T.J., 1995. Quantitative video sampling of coral reef benthos: large-scale application Coral Reefs 14, 35-46.

39. Chabanet, P., Loiseau, N., Join, J.-L., Ponton, D., 2012. VideoSolo, an autonomous video system for high-frequency monitoring of aquatic biota, applied to coral reef fishes in the Glorioso Islands (SWIO). Journal of Experimental Marine Biology and Ecology 430-431, 10-16.

40. Chatfield, B.S., Van Niel, K.P., Kendrick, G.A., Harvey, E.S., 2010. Combining environmental gradients to explain and predict the structure of demersal fish distributions. Journal of Biogeography 37, 593-605.

41. Colin, P.L., 1971. Interspecific Relationships of the Yellowhead Jawfish, Opistognathus aurifrons (Prisce, Opistognathidae). Copeia 1971, 469-473.

42. Colin, P.L., 1972. Daily Activity Patterns and Effects of Environmental Conditions on the Behavior of the yellowhead Jawfish, Opistognathus aurifons with Notes on its Ecology. Zoologica, N. Y. 57, 137169.

43. Colin, P.L., 1973. Burrowing Behavior of the yellowhead Jawfish, Opistognathus aurifrons. Copeia 1973, 84-90.

44. Colton, M.A., Swearer, S.E., 2010. A comparison of two survey methods: differences between underwater visual census and baited remote underwater video. Marine Ecology Progress Series 400, 19-36.

45. Condal, F., Aguzzi, J., Sarda, F., Nogueras, M., Cadena, J., Costa, C., Del Rio, J., Manuel, A., 2012. Seasonal rhythm in a Mediterranean coastal fish community as monitored by a cabled observatory. Marine Biology 159, 2809-2817.

46. Cooke, S.J., Schreer, J.F., 2002. Determination of fish community composition in the untempered regions of a thermal effluent canal - The efficacy of a fixed underwater videography system. Environmental Monitoring and Assessment 73, 109-129.

47. Cruz, I.C.S., kikushi, R.K.P., Leão, Z.M.A.N., 2008. Use of the video transect method for characterizing the Itacolomis reefs, eastern Brazil. Brazilian Journal of Oceanography 56, 271-280.

48. Cummings, W.C., Brahy, B.D., Spires, J.Y., 1966. Sounds production, schooling, and feeding habits of the margate, Haemulon album Cuvier, off North Bimini, Bahamas. Bulletin of Marine Science 16, 626640.

49. Cvitanovic, C., Bellwood, D.R., 2009. Local variation in herbivore feeding activity on an inshore reef of the Great Barrier Reef. Coral Reefs 28.

50. Davis, G.E., Anderson, T.W., 1989. Population estimates of four kelp forest fishes and an evaluation of three in situ assessment techniques. Bulletin of Marine Science 44, 1138-1151.

51. Dearden, P., Theberge, M., Yasué, M., 2010. Using underwater cameras to assess the effects of snorkeler and SCUBA diver presence on coral reef fish abundance, family richness, and species composition. Environmental Monitoring and Assessment 163, 531-538.

52. Dendrinos, P., Tounta, E., Karamanlidis, A.A., Legakis, A., Kotomatas, S., 2007. A Video Surveillance System for Monitoring the Endangered Mediterranean Monk Seal (Monachus monachus). Aquatic Mammals 33, 179-184.

53. Denny, C.M., Babcock, R.C., 2004. Do partial marine reserves protect reef fish assemblages? Biological Conservation 116, 119 - 129.

54. Denny, C.M., Willis, T.J., Babcock, R.C., 2004. Rapid recolonisation of snapper Pagrus auratus: Sparidae within an offshore island marine reserve after implementation of no-take status. Marine Ecology Progress Series 272, 183 - 190.

55. Dorman, S.R., Havrey, E.S., Newman, S.J., 2012. Bait Effects in Sampling Coral Reef Fish Assemblages with Stereo-BRUVs. PLoS ONE 7, e41538.

56. Dunbrack, R.L., 2006. In situ measurement of fish body length using perspective-based remote stereovideo. Fisheries Research 82, 327-331.

57. Dunbrack, R.L., 2008. Abundance trends for Hexanchus griseus, Bluntnose Sixgill Shark, and Hydrolagus colliei, Spotted Ratfish, counted at an automated underwater observation station in the Strait of Georgia, British Columbia. Canadian Field-Naturalist 122, 124-128. 
58. Dunbrack, R.L., Zielinski, R., 2003. Seasonal and diurnal activity of sixgill sharks (Hexanchus griseus) on a shallow water reef in the Strait of Georgia, British Columbia. Canadian Journal of Zoology 81, 1107-1111.

59. Dunlap, M., Pawlik, J.R., 1996. Video-monitored predation by Caribbean reef fishes on an array of mangrove and reef sponges. Marine Biology 126, 117-123.

60. Ellis, D., DeMartini, E., 1995. Evaluation of a video camera technique for indexing abundances of juvenile pink snapper, Pristipomoides filamentosus, and other Hawaiian insular shelf fishes. Fishery Bulletin 93, 67-77.

61. Enstipp, M.R., Gremillet, D., Jones, D.R., 2007. Investigating the functional link between prey abundance and seabird predatory performance. Marine Ecology Progress Series 331, 267-279.

62. Fedra, K., Machan, R., 1979. A Self-Contained Underwater Time-Lapse Camera for in situ Long-Term observations. Marine Biology 55, 239-246.

63. Fischer, P., Weber, A., Heine, G., Weber, H., 2007. Habitat structure and fish: assessing the role of habitat complexity for fish using a small, semiportable, 3-D underwater observatory. Limnology and Oceanography: Methods 5, 250-262.

64. Fitzpatrick, B.M., Harvey, E.S., Heyward, A.J., Twiggs, E.J., Colquhoun, J., 2012. Habitat Specialization in Tropical Continental Shelf Demersal Fish Assemblages. PLoS ONE 7.

65. Fox, R.J., Bellwood, D.R., 2007. Quantifying herbivory across a coral reef depth gradient. Marine Ecology Progress Series 339, 49-59.

66. Fox, R.J., Bellwood, D.R., 2008. Direct versus indirect methods of quantifying herbivore grazing impact on a coral reef. Marine Biology 154, 325-334.

67. Fox, R.J., Bellwood, D.R., 2008. Remote video bioassays reveal the potential feeding impact of the rabbitfish Siganus canaliculatus (f: Siganidae) on an inner-shelf reef of the Great Barrier Reef Coral Reefs 27, 605-615.

68. Francour, P., Liret, C., Harvey, E., 1999. Comparison of fish abundance estimates made by remote underwater video and visual census. Naturalista Sicil 23, 155 - 168.

69. Gladstone, W., Lindfield, S., Coleman, M., Kelaher, B., 2012. Optimisation of baited remote underwater video sampling designs for estuarine fish assemblages. Journal of Experimental Marine Biology and Ecology 429, 28-35.

70. Gledhill, C.T., Lyczkowski-Shultz, J., Rademacher, K., Kargard, E., Crist, G., Grace, M.A., 1996. Evaluation of video and acoustic index methods for assessing reef-fish populations. Journal of Marine Science 53, 483-485.

71. Goetze, J.S., Langlois, T.J., Egli, D.P., Harvey, E.S., 2011. Evidence of artisanal fishing impacts and depth refuge in assemblages of Fijian reef fish. Coral Reefs 30, 1-11.

72. Gomelyuk, V.E., 2009. Fish assemblages composition and structure in three shallow habitats in north Australian tropical bay, Garig Gunak Barlu National Park, Northern Territory, Australia. J Mar Biol Assoc Uk 89, 449-460.

73. Grabowski, T.B., Boswell, K.M., McAdam, B.J., Wells, R.J.D., Marteinsdottir, G., 2012. Characterization of Atlantic Cod Spawning Habitat and Behavior in Icelandic Coastal Waters. PLoS ONE 7.

74. Greene, L.E., Alevizon, W.S., 1989. Comparative accuracies of visual assessment methods for coral reef fishes. Bulletin of Marine Science 44, 899 - 912.

75. Grizzle, R.E., Brodeur, M.A., Abeels, H.A., Greene, J.K., 2008. Bottom habitat mapping using towed underwater videography: subtidal oyster reefs as an example application. Journal of Coastal Research 24, 103-109.

76. Hall, K.C., Hanlon, R.T., 2002. Principal features of the mating system of a large spawning aggregation of the giant Australian cuttlefish Sepia apama (Mollusca : Cephalopoda). Marine Biology 140, 533-545.

77. Handley, S., Kelly, S., Kelly, M., 2003. Non-destructive video image analysis method for measuring growth in sponge farming: preliminary results from the New Zealand bath-sponge Spongia (Heterofibria) manipulatus. New Zealand Journal of Marine and Freshwater Research 37, 613-621.

78. Hannah, R.W., Jones, S.A., 2012. Evaluating the behavioral impairment of escaping fish can help measure the effectiveness of bycatch reduction devices. Fisheries Research 131, 39-44. 
79. Harvey, E., Cappo, M., Shortis, M., Robson, S., Buchanan, J., Speare, P., 2003. The accuracy and precision of underwater measurements of length and maximum body depth of southern bluefin tuna (Thunnus maccoyii) with a stereo-video camera system. Fisheries Research 63, 315-326.

80. Harvey, E., Fletcher, D., Shortis, M., 2001. A comparison of the precision and accuracy of estimates of reef-fish lengths determined visually by divers with estimates produced by a stereo-video system. Fisheries Bulletin 99, 63-71.

81. Harvey, E., Fletcher, D., Shortis, M., 2001. Improving the statistical power of visual length estimates of reef fish: a comparison of divers and stereo-video. Fisheries Bulletin 99, 72 - 80.

82. Harvey, E., Fletcher, D., Shortis, M., 2002. Estimation of reef fish length by divers and by stereo-video. A first comparison of the accuracy and precision in the field on living fish under operational conditions. Fisheries Research 57, 255-265.

83. Harvey, E., Fletcher, D., Shortis, M.R., Kendrick, G.A., 2004. A comparison of underwater visual distance estimates made by scuba divers and a stereo-video system : implications for underwater visual census of reef fish abundance. Marine and Freshwater Research 55, 573-580.

84. Harvey, E., Shortis, M., 1995. A system for Stereo-Video Measurement of Sub-Tidal organisms. Marine Technology Society Journal 29, 10-22.

85. Harvey, E., Shortis, M., Stadler, M., Cappo, M., 2002. A comparison of the accuracy and precision of measurements from single and stereo-video systems. Marine Technology Society Journal 36, 38-49.

86. Harvey, E.S., Butler, J.J., McLean, D.L., Shand, J., 2012. Contrasting habitat use of diurnal and nocturnal fish assemblages in temperate Western Australia. Journal of Experimental Marine Biology and Ecology 426, 78-86.

87. Harvey, E.S., Cappo, M., Butler, J.J., Hall, N., Kendrick, G.A., 2007. Bait attraction affects the performance of remote underwater video stations in assessment of demersal fish community structure. Marine Ecology Progress Series 350, 245-254.

88. Harvey, E.S., Dorman, S.R., Fitzpatrick, C., Newman, S.J., McLean, D.L., 2012. Response of diurnal and nocturnal coral reef fish to protection from fishing: an assessment using baited remote underwater video. Coral Reefs 31, 939-950.

89. Harvey, E.S., Newman, S.J., McLean, D.L., Cappo, M., Meeuwig, J.J., Skeeper, C.L., 2012. Comparison of the relative efficiencies of stereo-BRUVs and traps for sampling tropical continental shelf demersal fishes. Fisheries Research 125-126, 108-120.

90. Harvey, E.S., Shortis, M.R., 1998. Calibration Stability of an Underwater Stereo Video System: Implications for Measurement Accuracy and Precision. Marine Technology Society Journal 32, 3 - 17.

91. Hayashizaki, K.-i., Ogawa, H., 2006. Introduction of underwater video system for the observation of coastal macroalgal vegetation. Coastal Marine Science 30, 196-200.

92. Heagney, E.C., Lynch, T.P., Babcock, R.C., Suthers, I.M., 2007. Pelagic fish assemblages assessed using mid-water baited video: standardising fish counts using bait plume size. Marine Ecology Progress Series 350, 255-266.

93. Hoey, A.S., 2010. Size matters: macroalgal height influences the feeding response of coral reef herbivores. Marine Ecology Progress Series 411, 299-U341.

94. Hoey, A.S., Bellwood, D.R., 2009. Limited Functional Redundancy in a High Diversity System: Single Species Dominates Key Ecological Process on Coral Reefs. Ecosystems 12, 1316-1328.

95. Hoey, A.S., Bellwood, D.R., 2010. Cross-shelf variation in browsing intensity on the Great Barrier Reef. Coral Reefs 29, 499-508.

96. Hoey, A.S., Bellwood, D.R., 2011. Suppression of herbivory by macroalgal density: a critical feedback on coral reefs? Ecology Letters 14, 267-273.

97. Holme, N.A., Barrett, R.L., 1977. A sledge with television and photographic cameras for quantitative investigation of the epifauna on the continental shelf. J Mar Biol Assoc Uk 57, 391-403.

98. Holt, D., 1967. opportunities for research utilizing underwater TV and acoustic systems. BioScience 17, 635-636.

99. Houk, P., Van Woesik, R., 2006. Coral Reef Benthic Video Surveys Facilitate Long-Term Monitoring in the Commonwealth of the Northern Mariana Islands: Toward an Optimal Sampling Strategy. Pacific Science 60, 177-189. 
100. Jan, R.-Q., Shao, Y.-T., Lin, F.-P., Fan, T.-Y., Tu, Y.-Y., Tsai, H.-S., Shao, K.-T., 2007. An underwater camera system for real-time coral reef fish monitoring. The Raffles Bulletin of Zoology 14, 273-279.

101. Jenkins, S.R., Mullen, C., Brand, A.R., 2004. Predator and scavenger aggregation to discarded bycatch from dredge fisheries: importance of damage level. Journal of Sea Research 51, 69-76.

102. Kenyon, J.C., Brainard, R.E., Hoeke, R.K., Parrish, F.A., Wilkinson, C.B., 2006. Towed-Diver Surveys, a Method for Mesoscale Spatial Assessment of Benthic Reef Habitat: A Case Study at Midway Atoll in the Hawaiian Archipelago. Coastal Management 34, 339-349.

103. Krohn, M.M., Boisclair, D., 1994. Use of a stereo-video system to estimate the energy expenditure of free swimming fish. Canadian Journal of Aquatic and Fisheries Science 51, 1119-1127.

104. Kronengold, M., Dann, R., Green, W.C., Loewenstein, J.M., 1964. An acoustic-video system for marine biological research : description of the system, in: Tavolga, W.N. (Ed.), Marine Bio-acoustics. Pergamon Press, New York, pp. 47-57.

105. Kumpf, H.E., 1964. Use of underwater television in bio-acoustic research, in: Tavolga, W.N. (Ed.), Marine Bio-Acoustics. Pergamon Press, New York, pp. 47-57.

106. Kumpf, H.E., Lowenstein, J.M., 1962. Undersea Observation Station. Sea Frontiers 8, 198-206.

107. LaFond, E.C., 1968. Photographic problems in oceanography, Underwater Photo-Optical Instrumentation Applications, Seminar Report, SPIE, San Diego, California, pp. 11-18.

108. LaFond, E.C., Barham, E.G., Armstrong, W.H., 1961. Use of underwater television in oceanographic studies of a shallow-water marine environment - Research and Development Report. U.S. Navy Electronics Laboratory, San Diego, California, p. 32.

109. Lam, K., Shin, P.K.S., Bradbeer, R., Randall, D., Ku, K.K.K., Hodgson, P., Cheung, S.G., 2006. A comparison of video and point intercept transect methods for monitoring subtropical coral communities. Journal of Experimental Marine Biology and Ecology 333, 115-128.

110. Langlois, T., Chabanet, P., Pelletier, D., Harvey, E., 2006. Baited underwater video for assessing reef fish populations in marine reserves, Secretariat of the South Pacific Community Fisheries Newsletter, pp. 53-56.

111. Langlois, T.J., Fitzpatrick, B.R., Fairclough, D.V., Wakefield, C.B., Hesp, S.A., McLean, D.L., Harvey, E.S., Meeuwig, J.J., 2012. Similarities between Line Fishing and Baited Stereo-Video Estimations of Length-Frequency: Novel Application of Kernel Density Estimates. PLoS ONE 7, e45973.

112. Langlois, T.J., Harvey, E.S., Fitzpatrick, B., Meeuwig, J.J., Shedrawi, G., Watson, D.L., 2010. Costefficient sampling of fish assemblages: comparison of baited video stations and diver video transects. Aquatic Biology 9, 155-168.

113. Langlois, T.J., Harvey, E.S., Meeuwig, J.J., 2012. Strong direct and inconsistent indirect effects of fishing found using stereo-video: Testing indicators from fisheries closures. Ecological Indicators 23, 524-534.

114. Lefèvre, C.D., Bellwood, D.R., 2011. Temporal variation in coral reef ecosystem processes: herbivory of macroalgae by fishes. Marine Ecology Progress Series 422, 239-251.

115. Leonard, G.H., Clark, R.P., 1993. Point quadrat versus video transect estimates of the cover of benthic red algae. Marine Ecology Progress Series 101, 203-208.

116. Leujak, W., Ormond, R.F.G., 2007. Comparative accuracy and efficiency of six coral community survey methods. Journal of Experimental Marine Biology and Ecology 351, 168 - 187.

117. Longo, G.O., Floeter, S.R., 2012. Comparison of remote video and diver's direct observations to quantify reef fishes feeding on benthos in coral and rocky reefs. Journal of Fish Biology 81, 1773-1780.

118. Lowry, M., Folpp, H., Gregson, M., 2011. Evaluation of an underwater solid state memory video system with application to fish abundance and diversity studies in south east Australia. Fisheries Research 110, 10-17.

119. Lowry, M., Folpp, H., Gregson, M., Suthers, I., 2012. Comparison of baited remote underwater video (BRUV) and underwater visual census (UVC) for assessment of artificial reefs in estuaries. Journal of Experimental Marine Biology and Ecology 416-417, 243-253.

120. Machan, R., Fedra, K., 1975. A New Towed Underwater Camera System for Wide-Range Benthic Surveys. Marine Biology 33, 75-84. 
121. Malcolm, H.A., Gladstone, W., Lindfield, S., Wraith, J., Lynch, T.P., 2007. Spatial and temporal variation in reef fish assemblages of marine parks in New South Wales, Australia-baited video observations. Marine Ecology Progress Series 350, 277-290.

122. Mantyka, C.S., Bellwood, D.R., 2007. Direct evaluation of macroalgal removal by herbivorous coral reef fishes. Coral Reefs 26, 435-442.

123. Mantyka, C.S., Bellwood, D.R., 2007. Macroalgal grazing selectivity among herbivorous coral reef fishes. Marine Ecology Progress Series 352, 177-185.

124. Martinez, I., Jones, E.G., Davie, S.L., Neat, F.C., Wigham, B.D., Priede, I.G., 2011. Variability in behaviour of four fish species attracted to baited underwater cameras in the North Sea Hydrobiologia 670, 23-34.

125. Masuda, R., Matsuda, K., Tanaka, M., 2012. Laboratory video recordings and underwater visual observations combined to reveal activity rhythm of red-spotted grouper and banded wrasse, and their natural assemblages. Environmental Biology of Fishes 95, 335-346.

126. McCauley, D.J., McLean, K.A., Bauer, J., Young, H.S., Micheli, F., 2012. Evaluating the performance of methods for estimating the abundance of rapidly declining coastal shark populations. Ecological Applications 22, 385-392.

127. McDonald, J.I., Coupland, G.T., Kendrick, G.A., 2006. Underwater video as a monitoring tool to detect change in seagrass cover. Journal of Environmental Management 80,148 - 155.

128. Mclean, D.L., Harvey, E.S., Fairclough, D.V., Newman, S.J., 2010. Large decline in the abundance of a targeted tropical lethrinid in areas open and closed to fishing. Marine Ecology Progress Series 418, 189-199.

129. Mclean, D.L., Harvey, E.S., Meeuwig, J.J., 2011. Declines in the abundance of coral trout (Plectropomus leopardus) in areas closed to fishing at the Houtman Abrolhos Islands, Western Australia. Journal of Experimental Marine Biology and Ecology 406, 71-78.

130. Meynecke, J.-O., Poole, G.C., Werry, J., Lee, S.Y., 2008. Use of PIT tag and underwater video recording in assessing estuarine fish movement in a high intertidal mangrove and salt marsh creek. Estuarine, Coastal and Shelf Science 79, 168-178.

131. Michalopoulos, C., Auster, P.J., Malatesta, R.J., 1992. A comparison of transect and species-time counts for assessing faunal abundance from video surveys. Marine Technology Society Journal 26, 2731.

132. Monk, J., lerodiaconou, D., Harvey, E., Rattray, A., Versace, V.L., 2012. Are We Predicting the Actual or Apparent Distribution of Temperate Marine Fishes? PLoS ONE 7.

133. Morrison, M., Carbines, G., 2006. Estimating the abundance and size structure of an estuarine population of the sparid Pagrus auratus, using a towed camera during nocturnal periods of inactivity, and comparisons with conventional sampling techniques. Fisheries Research 82, 150 - 161.

134. Myrberg, A.A., 1972. Social dominance and territoriality in the bicolor damselfish, Eupomacentrus partitus (Poey) (Pisces: Pomacentridae). Behaviour 41, 207-231.

135. Myrberg, A.A., 1972. Using sound to influence the behaviour of free-ranging maruine animals, in: Winn, H.E., Olla, B.L. (Eds.), Behavior of marine animals-Current perspectives in research. PLenum Press, New York, pp. 435-468.

136. Myrberg, A.A., 1973. Underwater television-a tool for the marine biologist. Bulletin of Marine Science 23, 825-836.

137. Myrberg, A.A., Banner, A., Richard, J.D., 1969. Shark attraction using a video-acoustic system. Marine Biology 2, 264-276.

138. Myrberg, A.A., Spires, J.Y., 1972. Sound discrimination by the bicolor damselfish, Eupomacentrus partitus. Journal of Experimental Biology 57, 727-735.

139. Ninio, R., Delean, S., Osborne, K., Sweatman, H., 2003. Estimating cover of benthic organisms from underwater video images: variability associated with multiple observers. marine Ecology Progress Series 265, 107-116.

140. Ninio, R., Meekan, M., Done, T., Sweatman, H., 2000. Temporal patterns in coral assemblages on the Great Barrier Reef from local to large spatial scales. Marine Ecology Progress Series 194, 65-74. 
141. Norris, J.G., Wyllie-Echeverria, S., Mumford, T., Bailey, A., Turner, T., 1997. Estimating basal area coverage of subtidal seagrass beds using underwater videography. Aquatic Botany 58, 269-287.

142. Parker, R.O., Chester, A.J., Nelson, R.S., 1994. A video transect method for estimating reef fish abundance, composition, and habitat utilization at Gray's Reef National Marine Sanctuary, Georgia. Fishery bulletin 92, 787-799.

143. Pelletier, D., Leleu, K., Mallet, D., Mou-Tham, G., Hervé, G., Boureau, M., Guilpart, N., 2012. Remote High-Definition Rotating Video Enables Fast Spatial Survey of Marine Underwater Macrofauna and Habitats. PLoS ONE 7, e30536.

144. Pelletier, D., Leleu, K., Mou-Tham, G., Guillemot, N., Chabanet, P., 2011. Comparison of visual census and high definition video transects for monitoring coral reef fish assemblages. Fisheries Research 107, $84-93$.

145. Petrell, R.J., Shi, X., Ward, R.K., Naiberg, A., Savage, C.R., 1997. Determining fish size and swimming speed in cages and tanks using simple video techniques. Aquacultural Engineering 16, 63-84.

146. Picciulin, M., Sebastianutto, L., Codarin, A., Farina, A., Ferrero, E.A., 2010. In situ behavioural responses to boat noise exposure of Gobius cruentatus (Gmelin, 1789

147. Richard, J.D., 1968. Fish Attraction with Pulsed Low-Frequency Sound. Journal of Fisheries Research Board of Canada 25, 1441-1452.

148. Riegl, B., Korrubel, J.L., Martin, C., 2001. Mapping and monitoring of coral communities and their spatial patterns using a surface-based video method from a vessel. Bulletin of Marine Science 69, 869880.

149. Rogers, C.S., Miller, J., 2001. Coral bleaching, hurricane damage, and benthic cover on coral reefs in St. John, U.S. Virgin Islands: A comparison of surveys with the chain transect method and videography Bulletin of Marine Science 69, 459-470.

150. Rooper, C.N., Zimmermann, M., 2007. A bottom-up methodology for integrating underwater video and acoustic mapping for seafloor substrate classification. Continental Shelf Research 27, 947-957.

151. Rosenkranz, G.E., Byersdorfer, S.C., 2004. Video scallop survey in the eastern Gulf of Alaska, USA. Fisheries Research 69, 131-140.

152. Schultz, A.L., Malcolm, H.A., Bucher, D.J., Smith, S.D.A., 2012. Effects of Reef Proximity on the Structure of Fish Assemblages of Unconsolidated Substrata. PLoS ONE 7.

153. Shucksmith, R., Hinz, H., Bergmann, M., Kaiser, M.J., 2006. Evaluation of habitat use by adult plaice (Pleuronectes platessa L.) using underwater video survey techniques. Journal of Sea Research 56, 317-328.

154. Smith, C.J., Banks, A.C., Papadopoulou, K.-N., 2007. Improving the quantitative estimation of trawling impacts from sidescan-sonar and underwater-video imagery. ICES Journal of Marine Science 64, 1692-1701.

155. Smith, C.L., Tyler, J.C., 1973. Population ecology of a Bahamian suprabenthic shore fish assemblage. American Museum novitates 2528, 37p.

156. Spencer, M.L., Stoner, A.W., Ryer, C.H., Munk, J.E., 2005. A towed camera sled for estimating abundance of juvenile flatfishes and habitat characteristics: Comparison with beam trawls and divers. Estuarine, Coastal and Shelf Science 64, 497 - 503.

157. Steinberg, J.C., Cummings, W.C., Brahy, B.D., MacBain Spires, J.Y., 1965. Further Bio-Acoustic Studies off the West Coast of North Bimini, Bahamas Bulletin of Marine Science 15, 942-963.

158. Steinberg, J.C., Koczy, F.F., 1964. An acoustic-video system for marine biological research : Objectives and requirements, in: Tavolga, W.N. (Ed.), Marine Bio-acoustics. Pergamon Press, New York, pp. 1-9.

159. Stevenson, R.A., 1967. Underwater television. Oceanology International 2, 30-35.

160. Stevenson, R.A., Myrberg, A.A., 1966. Behavior of the bicolor damselfish, Eupomacentrus partitus, in the field and in the aquarium. American Society of zoologists 6, 516.

161. Stobart, B., García-Charton, J.A., Espejo, C., Rochel, E., Goñi, R., Reñones, O., Herrero, A., Crec'hriou, R., Polti, S., Marcos, C., Planes, S., Pérez-Ruzafa, A., 2007. A baited underwater video technique to assess shallow-water Mediterranean fish assemblages: Methodological evaluation. Journal of Experimental Marine Biology and Ecology 345 158-174. 
162. Stokesbury, K.D.E., harris, B., P., Marino, M.C., Nogueira, J.I., 2004. Estimation of sea scallop abundance using a video survey in off-shore US waters. Journal of Shellfish Research 23, 33-40.

163. Stoner, A.W., Laurel, B.J., Hurst, T.P., 2008. Using a baited camera to assess relative abundance of juvenile Pacific cod: Field and laboratory trials. Journal of Experimental Marine Biology and Ecology 254, 202-211.

164. Tessier, E., 2005. Dynamique des peuplements ichtyologiques associés aux récifs artificiels à l'île de la Réunion (ouest de l'océan Indien) - Implication dans la gestion des pêcheries côtières., Ecologie Marine. Université de la Réunion, p. 254.

165. Tessier, E., Chabanet, P., Pothin, K., Soriae, M., Lasserre, G., 2005. Visual censuses of tropical fish aggregations on artificial reefs: slate versus video recording techniques. Journal of Experimental Marine Biology and Ecology 315 17-30.

166. Tilot, V., Leujak, W., Ormond, R.F.G., Ashworth, J.A., Mabrouk, A., 2008. Monitoring of South Sinai coral reefs: influence of natural and anthropogenic factors. Aquatic Conservation: Marine and Freshwater Ecosystems 18, 1109-1126.

167. Tyne, J.A., Loneragan, N.R., Krützen, M., Allen, S.J., Bejder, L., 2010. An integrated data management and video system for sampling aquatic benthos. Marine and Freshwater Research 61, 1023-1028.

168. Vergés, A., Bennett, S., Bellwood, D., 2012. Diversity among macroalgae-consuming fishes in coral reefs: a transcontinental comparison. PLoS ONE 7, e45543.

169. Vogt, H., Montebon, A.R.F., Alcala, M.L.R., 1997. Underwater video sampling: an effective method for coral reef surveys?, in: Lessios, H.A., Macintyre, I.G. (Eds.), Proceedings of the 8th International Coral Reef Symposium Vol. 2, Smithsonian Tropical Research Institute, Panama, pp. 1447-1452.

170. Watson, D.L., Anderson, M.J., Kendrick, G.A., Nardi, K., Harvey, E.S., 2009. Effects of protection from fishing on the lengths of targeted and non-targeted fish species at the Houtman Abrolhos Islands, Western Australia. Marine Ecology Progress Series 384, 241-249.

171. Watson, D.L., Harvey, E.S., 2007. Behaviour of temperate and sub-tropical reef fishes towards a stationary SCUBA diver. Marine and Freshwater Behaviour and Physiology 40, 85-103.

172. Watson, D.L., Harvey, E.S., Anderson, M.J., Kendrick, G.A., 2005. A comparison of temperate reef fish assemblages recorded by three underwater stereo-video techniques. Marine Biology 148, 415 - 425.

173. Watson, D.L., Harvey, E.S., Fitzpatrick, B.M., Langlois, T.J., Shedrawi, G., 2010. Assessing reef fish assemblage structure: how do different stereo-video techniques compare? Marine Biology 157, 1237 1250.

174. Watson, D.L., Harvey, E.S., Kendrick, G.A., Nardi, K., Anderson, M.J., 2007. Protection from fishing alters the species composition of fish assemblages in a temperate-tropical transition zone. Marine Biology 152, 1197-1206.

175. Wells, R.J.D., Boswell, K.A., Cowan, J.H., Jr., Patterson, W.F., 2008. Size selectivity of sampling gears targeting red snapper in the northern Gulf of Mexico. Fisheries Research 89, 294-299.

176. Westera, M., Lavery, P., Hyndes, G., 2003. Differences in recreationally targeted fishes between protected and fished areas of a coral reef marine park. Journal of Experimental Marine Biology and Ecology 294, 145- 168.

177. Willis, T.J., Babcock, R.C., 2000. A baited underwater video system for the determination of relative density of carnivorous reef fish. Marine and Freshwater Research 51, 755-763.

178. Willis, T.J., Millar, R.B., 2005. Using marine reserves to estimate fishing mortality. Ecology Letters 8, 47-52.

179. Willis, T.J., Millar, R.B., Babcock, R.C., 2000. Detection of spatial variability in relative density of fishes: comparison of visual census, angling, and baited underwater video. Marine Ecology Progress Series $198,249-260$.

180. Willis, T.J., Millar, R.B., Babcock, R.C., 2003. Protection of exploited fish in temperate regions: high density and biomass of snapper Pagrus auratus (Sparidae) in northern New Zealand marine reserves. Journal of Applied Ecology 40, 214 - 227.

181. Wraith, J.A., 2007. Assessing reef fish assemblages in a temperate marine park using baited remote underwater video. University of Wollongong, p. 100. 
182. Young, M.A.L., Bellwood, D.R., 2012. Fish predation on sea urchins on the Great Barrier Reef. Coral Reefs 31, 731-738. 